\title{
THE ROLE OF GUARANTEES IN BLENDED FINANCE
}

\author{
Weronika Garbacz, David Vilalta, Lasse Moller
}
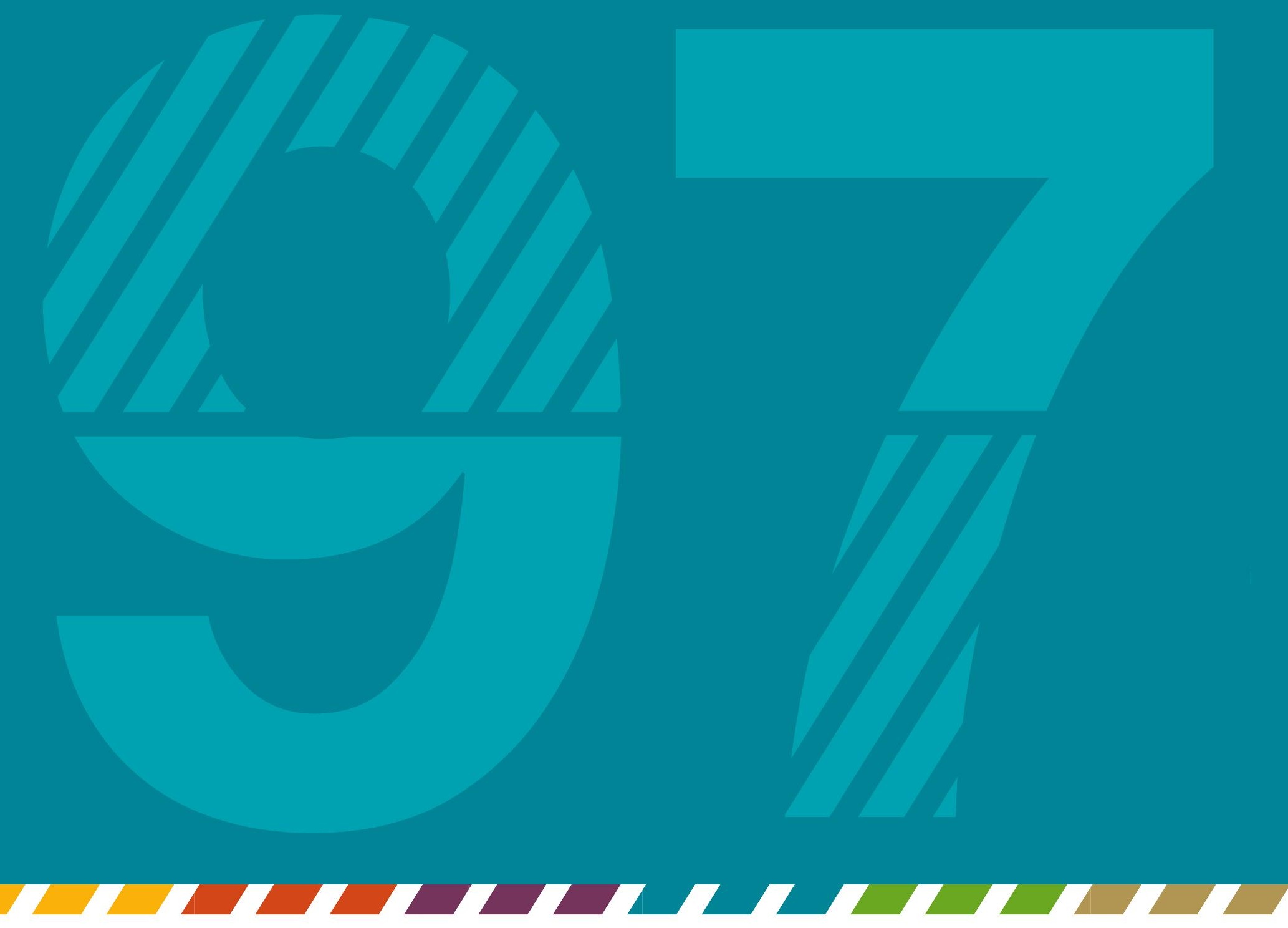

\section{OECD DEVELOPMENT CO-OPERATION WORKING PAPER 97}

Authorised for publication by Jorge Moreira da Silva, Director, Development Co-operation Directorate 



\section{Disclaimer}

OECD Working Papers do not represent the official views of the OECD or of its member countries. The opinions expressed and arguments employed are those of the author(s).

Working Papers describe preliminary results or research in progress by the author(s) and are published to stimulate discussion on a broad range of issues on which the OECD works. Comments on this Working Paper are welcome and may be sent to DCDFSDBlendedFinance@oecd.org, Development Co-ordination Directorate, OECD, 2 rue André-Pascal, 75775 Paris Cedex 16, France.

This document, as well as any data and any map included herein, are without prejudice to the status of or sovereignty over any territory, to the delimitation of international frontiers and boundaries and to the name of any territory, city or area.

Please cite this paper as Garbacz W., D. Vilalta and L. Moller (2021), "The role of guarantees in blended finance”, OECD Development Co-operation Working Papers, No 97 OECD Publishing, Paris. 


\section{Abstract}

The paper discusses the role of guarantees as a blended finance tool. The coronavirus (COVID-19) crisis provides a new context for donors to assess the relevance of guarantees in addressing challenges linked with a sustainable recovery. The paper argues that there may be significant scope for more extensive and better use of guarantees to build back better in response to the crisis. The paper also discusses how guarantees can promote more investment particularly in underdeveloped and underserved markets, such as the least developed countries (LDCs). 


\section{Foreword}

This Working Paper has been prepared as an input to the discussion on blended finance solutions in the OECD Development Assistance Committee (DAC) Community of Practice (CoP) on Private Finance for Sustainable Development (PFSD). It focuses on the role of development guarantees as an instrument in the blended finance toolbox to mobilise private investment towards achieving the SDGs. It argues that there may be significant scope for more extensive and better use of guarantees to build back better in response to the COVID-19 crisis. The paper also investigates guarantees' utility in promoting more investment in underdeveloped and underserved markets, often found in the least developed countries (LDCs).

The paper situates itself within an ongoing discussion around guarantees as a development instrument. Key publications that have informed the analysis include the OECD working paper on the first-ever survey of the guarantee portfolios of a range of bilateral aid agencies, development finance institutions and international financial institutions (Mirabile, Benn and Sangaré, 2013 ${ }_{[1]}$ ). It also draws on the Overseas Development Institute's (ODI) review of guarantees on the part of multilateral development banks (MDBs) (Humphrey and Prizzon, 2014[2] $)$. More recent studies discussing the benefits and limitations of using guarantees for development purposes include the Center for Strategic and International Studies' (CSIS) 2019 report, which identifies a set of innovations in the use of guarantees outside of the established MDBs business model (Bandura and Ramanujam, 2019[3] $)$. The Milken Institute-OECD joint report presenting key policy and regulatory issues impeding the development of guarantees and insurance (Lee, Betru and Horrocks, 2018[4] has also inspired the analysis, together with the Center for Global Development's (CGD) working paper which compares guarantees with other instruments (Barder and Talbot, 2015 $5_{[5]}$ ). The work in this paper also draws on the recent evaluation study on credit guarantee schemes commissioned by the Ministry of Foreign Affairs/Danida (Hansen, Rand and Winckler Andersen, 2020[6]), Sida's evaluation of their use of guarantees for market development and poverty reduction (Sida, 2016 $6_{[7]}$ ) and a comprehensive evaluation of the World Bank Group guarantee instruments (World Bank, 2009 $9_{[8]}$ ). Other consulted publications include documents relating to the EU's External Investment Plan, which discuss the main workings and primary goals of one of the latest and largest guarantee programmes - the European Fund for Sustainable Development (European Commission, 2020[9]) - as well as various articles and documents from Convergence that touch upon relevant areas, from key definitions to current guarantee market trends.

The COVID-19 crisis provides a new context for donors to revisit the use of guarantees and assess their relevance in addressing the challenges linked with sustainable recovery. It is the hope that the paper will inspire donor agencies and other relevant stakeholders to make more extensive and better use of guarantees as an instrument for development. 


\section{Acknowledgements}

This Working Paper was prepared by the OECD Development Co-operation Directorate (DCD), headed by Director Jorge Moreira da Silva. Paul Horrocks, Head of Private Finance for Sustainable Development Unit, managed and led the work under the strategic leadership of Haje Schütte, Senior Counsellor and Head of Financing for Sustainable Development Division. The paper was authored by Weronika Garbacz, David Vilalta and Lasse Moller.

The authors would like to thank Kathleen Dominique (OECD Environment Directorate) and Catriona Marshall (OECD Directorate for Financial and Enterprise Affairs) for peer reviewing the paper. The authors would also like to thank Cécile Sangaré, Tomáš Hos, Julia Benn, Priscilla Boiardi, Valentina Bellesi, Esme Stout and Faty Dembele (OECD Development Co-operation Directorate) for their valuable inputs and comments on previous versions of this paper.

The analysis underlying this document is based on information gathered through desk research and expert interviews conducted by the authors from June to December 2020. The interviewees included experts from: Ministry of Foreign Affairs of Denmark/Danida, Swedish International Development Co-operation Agency, CDC Group, Ministry of Foreign Affairs of the Netherlands, Ministry of Foreign Affairs of the Czech Republic, Proparco, the French Development Agency, Czech-Moravian Guarantee and Development Bank, Multilateral Investment Guarantee Agency, African Development Bank, International Finance Corporation, European Commission, GuarantCo (a Private Infrastructure Development Group (PIDG) company), Africa Guarantee Fund, Rural Development Fund in Ghana, European Centre for Development Policy Management, Insurance Development Forum, Co-Guarantee Platform, Indiana University, Danish Institute for International Studies, the University of Copenhagen, the Milken Institute, and the Millennium Challenge Corporation. The authors would like to thank all the interviewees and experts consulted.

An earlier version of the paper was presented and discussed at the meeting of the DAC Community of Practice on Private Finance for Sustainable Development (CoP-PFSD) on 2 December 2020. The authors would like to especially thank Vilém Řehák (Czech-Moravian Guarantee and Development Bank), Nerea Craviotto (Eurodad), Anna Holmryd (Ministry of Foreign Affairs of Sweden) and Magnus Cedergren (Danida) for their further comments and inputs to the paper. 


\section{Table of contents}

$\begin{array}{ll}\text { Abstract } & 4\end{array}$

Foreword 5

Acknowledgements 6

Abbreviations and acronyms $\quad 9$

Executive summary 11

Benefits and challenges of using guarantees 11

Why guarantees are particularly relevant in the coronavirus (COVID-19) context and in the least developed countries (LDCs) 11

Need for collaboration, additionality and sustainability 12

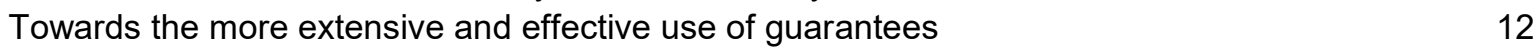

1 Guarantees for development: Setting the scene 13

$\begin{array}{lr}\text { Defining guarantees } & 13\end{array}$

$\begin{array}{lr}\text { Types of guarantees } & 14\end{array}$

$\begin{array}{lr}\text { Overview of guarantee providers } & 16\end{array}$

2 Key benefits and limitations to using guarantees for development at scale 25

Rationale for using guarantees for development and their benefits $\quad 25$

Limitations to using guarantees for development $\quad 29$

3 How can guarantees be used to specifically target the least developed countries and underinvested sectors?

Spurring local currency financing and domestic resource mobilisation in LDCs 33

Backstopping financing for large-scale infrastructure projects $\quad 34$

$\begin{array}{ll}\text { Mitigating political risks } & 35\end{array}$

Using guarantees as triggers for market change $\quad 35$

Collaboration among guarantee providers for reaching underserved markets 36

$\begin{array}{lr}\text { Supporting specialised guarantee providers } & 37\end{array}$

4 Why guarantees may be particularly relevant in the coronavirus (COVID-19) context

Coronavirus (COVID-19) and guarantees 40

Scaling up short-term responses to coronavirus (COVID-19) by expanding small and mediumsized enterprise finance and supporting viable businesses 
The role of guarantees in supporting health systems during the crisis 42

5 What could be done to incentivise and improve the use of guarantees? 44

Improving incentive structures for donors in terms of the ODA-eligibility of guarantees 44

Co-ordinating guarantees and insurance to deliver on development 45

$\begin{array}{ll}\text { Other best practices to improve the use of guarantees } & 47\end{array}$

$\begin{array}{ll}\text { References } & 49\end{array}$

Notes $\quad 54$

\section{Figures}

Figure 1.1. Amounts mobilised by guarantees by DAC providers, 2012 - 2018 average, USD thousands 20 Figure 2.1. Amounts mobilised by year and instrument 2012-2018

Figure 2.2. Amounts mobilised by region, 2017-2018 average 27

\section{Boxes}

Box 1.1. Funded vs. unfunded guarantees $\quad 14$

Box 1.2. Loan, portable and portfolio guarantees $r$

Box 1.3. Bond, equity and balance sheet guarantees 16

Box 1.4. Sida's use of development guarantees $\quad 18$

Box 1.5. International Development Co-operation Guarantee by the Czech Republic 19

Box 1.6. Multilateral Investment Guarantee Agency's political risk insurance and credit enhancement 21

Box 1.7. Guarantees by GuarantCo 22

Box 1.8. European Fund for Sustainable Development 23

Box 2.1. Measuring private finance mobilised by guarantees $\quad 26$

$\begin{array}{ll}\text { Box 2.2. Mobilisation vs. leverage ratio of guarantees } & 27\end{array}$

Box 2.3. Additionality - definitions $\quad 28$

Box 2.4. Different approaches to pricing of development guarantees 32

Box 3.1. IFC's Partial Credit Guarantee (PCG) for Bonds $\quad 34$

Box 3.2. InfraCredit - Infrastructure Credit Guarantee Company $\quad 35$

Box 3.3. Co-Guarantee Platform $\quad 37$

Box 3.4. The African Guarantee Fund (AGF) $\quad 38$

Box 4.1. MIGA's COVID-19 response $\quad 41$

Box 4.2. Boosting small and medium-sized enterprise finance during COVID-19

Box 4.3. European Health Guarantee Platform for Africa 43

Box 5.1. Lack of agreement on the ODA-eligibility of individual guarantees 44

Box 5.2. Insurance versus guarantees $\quad 46$ 


\section{Abbreviations and acronyms}

AECID Agencia Española de Co-operación Internacional para el Desarrollo /Spanish Agency for International Development

AFD Agence française de développement / French Development Agency

AfDB African Development Bank

AGF Africa Guarantee Fund

ALCBGP African Local Currency Bond Guarantee Programme

ATI African Trade Insurance Agency

BFRG Bank Fund Raising Guarantee

BIO Belgian Investment Company for Developing Countries

BIS Bank of International Settlements

CDP Cassa Depositi e Prestiti S.p.A.

CGP Co-Guarantee Platform

ČMZRB Czech-Moravian Guarantee and Development Bank

COEFIDES Compañía Española de Financiación del Desarrollo / Spanish Company for Development Financing

CRS Creditor Reporting System

DAC Development Assistance Committee

DEG Deutsche Investitions- und Entwicklungsgesellschaft / German Investment and Development Corporation

DFC United States International Development Finance Corporation

DFI Development finance institution

EBRD European Bank for Reconstruction and Development

EFSD European Fund for Sustainable Development

EG Equity Guarantee

EU European Union

FDI Foreign direct investment

FMO Nederlandse Financierings-Maatschappij voor Ontwikkelingslanden N.V / Entrepreneurial Development Bank

GGF Green Guarantee Facility 
GIIN Global Impact Investing Network

HLM High level meeting

IBRD International Bank of Reconstruction and Development

ICIEC Islamic Corporation for the Insurance of Investment \& Export Credit

IDA International Development Association

IDCG International Development Co-operation Guarantee

IDF Insurance Development Forum

IFU Danish Investment Fund for Developing Countries

KfW Kreditanstalt für Wiederaufbau / Credit Institute for Reconstruction

LDC Least developed country

LIC Low income country

LIG Loan individual Guarantee

LPG Loan portfolio guarantee

M\&E Monitoring \& evaluation

MDB Multilateral development bank

MFA Ministry of foreign affairs

MIC Middle income country

MIGA Multilateral Investment Guarantee Agency

ODA Official development assistance

ODI Overseas Development Institute

OECD Organisation for Economic Co-operation and Development

OeEB Oesterreichische Entwicklungsbank / Development Bank of Austria

PCG Partial credit guarantee

PFI Partner financial institution

PPA Power purchase agreement

PSI Private sector instruments

SDGs Sustainable Development Goals

Sida $\quad$ Swedish International Development Co-operation Agency

SME Small and medium-sized enterprise

SOFID Sociedade para o Financiamento do Desenvolvimento / Portuguese Development Finance Institution

USAID U.S. Agency for International Development

WEF World Economic Forum 


\section{Executive summary}

\section{Benefits and challenges of using guarantees}

Guarantees have a number of benefits as a blended finance instrument. Firstly, they do not require an immediate outflow of funds by donors and are particularly useful for optimising budgets for development while allowing guarantors to leverage their balance sheets more efficiently. In addition, guarantees have proven to be the most effective instrument for mobilising private finance. Guarantees are also uniquely suited to mitigate commercial, credit and political risks, and they can bring financial additionality by changing the risk-return profile of investments and alleviating credit restrictions for underserved borrowers.

At the same time, several challenges restrict their widespread use among donors. Guarantees are not official development assistance (ODA) eligible, which serves to limit Development Assistance Committee (DAC) members' willingness to use the instrument in their bilateral programmes. Guarantees also introduce a third party into deals, which adds to the instrument's complexity. Deploying guarantees requires specific financial and risk-management expertise, which may not be readily available within aid agencies. Other obstacles to using guarantees are linked to supply-side constraints, especially in the least developed markets. Additionally, limited awareness and evidence regarding the use of guarantees for development purposes also constrain their use. Among multilateral development banks (MDBs) there is a number of impediments to using guarantees, and measuring the development impact of guarantees often proves challenging and remains a concern.

\section{Why guarantees are particularly relevant in the coronavirus (COVID-19) context and in the least developed countries (LDCs)}

The COVID-19 crisis provides a new context for donors to revisit the use of guarantees and assess their potential and relevance in addressing the challenges linked with a sustainable recovery. Guarantees already feature in post-COVID-19 economic recovery plans across both developed and developing countries. The COVID-19 crisis has increased the need for guarantees that would allow donors to do more with less through balance sheet optimisation. Unfunded guarantees are particularly relevant for the COVID19-induced climate of constrained public budgets and growing public debt, and have proven to be a relevant tool for alleviating SME's cash-flow problems.

De-risking investments and attracting development finance is most needed - but also most challenging in underdeveloped and underserved markets, such as the LDCs. Guarantees offer a particularly relevant solution for supporting the development of local financial markets due to their ability to increase local currency financing, which is key for many of the LDCs. Guarantees are also backstopping financing for large infrastructure projects where risks tend to be high, and they are used as initial trigger for market change in emerging economies where the economic environment is often volatile. 


\section{Need for collaboration, additionality and sustainability}

Complex and risky environments pose a challenge to the use of guarantees by individual providers, and collaboration between providers is therefore key to implementing more effective support packages that would address both risk and return constraints. Although a Co-Guarantee Platform that allow institutions with different risk mitigation products to come together and work on specific projects already exists, providers of guarantees need to better collaborate in order to address both risk and return constraints, as well as to generate more financial and development additionality.

While, in some cases, donor-backed guarantee providers subsidise part of the guarantee fee, this should be carefully assessed in order to ensure that donors do not crowd out private finance. In markets serviced by a number of guarantee providers, especially private ones, it is important that donor-backed guarantees are additional to existing financing and do not crowd out private guarantors. While designing guarantee schemes, donors should pay particular attention to ensuring their financial sustainability. Guarantees should ideally be time-bound, with credible expectations that they will be phased out over time.

\section{Towards the more extensive and effective use of guarantees}

A complex mix of incentives drives the use of guarantees. Agreement by the DAC on ODA-eligibility could strengthen the incentive for using the instrument. A second issue concerns the need for a coherent approach to risk-management at sovereign and sub-sovereign levels, including the need for a better coordination between guarantees and insurance products. Other suggestions to foster the more extensive and effective use of guarantees include: promoting partial guarantees (with a coverage ratio lower than $100 \%$ ) and market rates to ensure accountability; promoting more competition in the market; standardising guarantees to allow for economies of scale; making better use of unfunded guarantees; and aligning incentives for MDBs to promote the use of guarantees. Importantly, the paper argues that the use of guarantees should follow the OECD DAC Blended Finance Principles for Unlocking Commercial Finance for the SDGs. First, guarantees should be used when there is a development objective aligned with the SDGs. Second, the goal of the instrument should be to mobilise as much commercial finance as possible. Third, the ultimate impact of the guarantee should be felt in the local financial market. Fourth, partnerships and collaboration should be incentivised among providers and the private sector. Fifth, effective impact evaluation and monitoring should be ensured throughout the process.

More research would be useful to improve the knowledge and better guide the use of guarantees. This includes a better understanding of how bilateral agencies in the DAC are already using guarantees, a systematic collection of case studies to inform and inspire the use of guarantees, especially in the COVID19 context and in underserved markets, and a more detailed discussion of incentives for using guarantees (including ODA eligibility). Further research would also be useful on the types of sectors and investments that have the most potential for optimising the use of development guarantees, as well as on the key characteristics of the enabling environment that needs to be in place to ensure the effective use of this instrument. 


\section{Guarantees for development: Setting the scene}

\section{Defining guarantees}

The OECD defines guarantees as "a type of insurance policy protecting banks and investors from the risks of non-payment" (Mirabile, Benn and Sangaré, 2013[1]). More technically, a guarantee is a legally binding agreement under which the guarantor agrees to pay part or all of an amount due on a loan, equity, or other instrument in the event of non-payment by the obligor (or loss of value, in the case of investment). In this document, the term "development guarantees" is used interchangeably with "guarantees for development" and denotes a "special category of official guarantees that back projects promoting the development and welfare of developing countries" (Mirabile, Benn and Sangaré, 2013[1]). Guarantees can serve a variety of development purposes, e.g. they can back-stop high-impact investments in risky markets, de-risk a local bank's loan portfolio for small and medium enterprises (SMEs), or transfer risks from local financial institutions to service underserved borrowers.

Guarantees differ according to types of risk (commercial or political), nature of instruments (debt, equity or both), amounts (full or partial coverage), and payments (principal and/or interest). In relation to the commercial and political risks, the first category designates the risks of default on debt service obligations (the borrower's inability to meet its financial obligations). Political risks, on the other hand, are associated with government actions "which deny or restrict the right of an investor to use or benefit from his/her assets; or which reduce the value of the firm" (MIGA, 2008 $\left.{ }_{[10]}\right)$. Political risks are usually linked with wars, civil unrest, government seizure of property, regulatory changes, as well as restrictions on foreign exchange transfer.

Another important distinction is between funded and unfunded guarantees. Funded schemes require at least part of the guaranteed amount to be kept in escrow for the lifetime of the guarantee, whereas unfunded guarantees mean that only the expected loss from guarantee contracts is kept in reserves. Backed by the rating of the sovereign, bilateral unfunded schemes can mobilise capital more efficiently as there is no capital set aside or reserved on the guarantor's balance sheet above the provisioning for the expected loss. The loss is financed through guarantee fees, which in turn may be subsidised by ODA. With unfunded schemes, appropriate methods and capacity for risk assessment become even more important. 


\section{Box 1.1. Funded vs, unfunded guarantees}

Funded guarantees: When a guarantee is issued, a significant part of the guaranteed amount is set aside to be held in escrow to cover a potential default. For example, the European Fund for Sustainable Development (EFSD) requires $50 \%$ of the guaranteed amount to be held as provisions. Funded guarantees are used to benefit from the significantly lower balance sheet risk implied by high levels of provisions.

Unfunded guarantees: In an unfunded guarantee, only the expected loss from the guarantee is kept in reserve. For example, based on the expected loss, Sida charges a guarantee fee to the organisation receiving the guarantee. When necessary, a part of the guarantee fee can be subsidised by Sida grants. The expected loss amount including subsidy is paid to the state guarantee service account. The funds from the service account are used for the payments in case of defaults. No other Sida grants are used for the repayment of defaults. This guarantee reserve is backed by an unlimited credit at the National Debt Office. Unfunded guarantees are broadly used because they enable a much larger leveraging of commercial finance relative to provisions.

Source: (Sida, 2017[11]), Information Brief: Guarantees. Unlocking capital for development efforts, https://www.sida.se/English/publications/160271/guarantees

(European Commission, 2017 $\left.{ }_{[12]}\right)$, Your guide to the EU External Investment Plan, https://ec.europa.eu/commission/sites/betapolitical/files/external-investment-plan-guide-nov17_en.pdf

The OECD Creditor Reporting System (CRS) does not make a distinction between guarantees and insurance. For the analysis undertaken in this document, both instruments will be treated jointly, as they perform essentially the same functions and are both contingent liabilities. Yet, there are certain differences between guarantees and insurance. Guarantees are often financial in nature and result in payment by a guarantor in the event of non-payment by a guaranteed entity to a third party. While insurance policies can serve the same function, they often include additional conditions that need to occur before payment takes place. These conditions can often take the form of particular risks, situations, types of damage and contingent damages and losses. More detailed discussion on the potential of co-ordinating guarantees and insurance to deliver on development is presented chapter 5 (Box 5.2).

\section{Types of guarantees}

Among the most common types of guarantees are loan guarantees and portfolio guarantees. Other types also include portable guarantees, bond guarantees, equity guarantees, and balance sheet guarantees. In order to analyse the types of private finance attracted by the instrument in question, it is useful to divide guarantees into two categories: (i) a contract between a guarantee provider and financial institutions, and (ii) a contract between a guarantee provider and investors.

\section{Guarantee contracts between a guarantee provider and financial institutions}

Loan guarantees, portfolio guarantees, and portable guarantees target the relationship between a finance provider and one or more clients with the need for additional finance. In these cases, the guarantee's purpose is to de-risk the financial institution's lending. Therefore, the commercial finance mobilised with these types of guarantees encompasses banks' and other finance providers' own financial resources. 
Issuing such guarantees creates financial additionality because it unlocks the beneficiary institutions' capacity to increase their lending. It also has local buy-in and participation. Loan and portfolio guarantees are the most widely used types of guarantees. For instance, portfolio guarantees accounted for $60 \%$ of Sida's portfolio in 2019 (Sida, 2019 [13]), and they were also used by USAID and the African Guarantee Fund (AGF). Portable guarantees have been offered by USAID, Sida and GuarantCo.

\section{Box 1.2. Loan, portable and portfolio guarantees}

Loan guarantees cover a specific loan made to a pre-established borrower by a financial institution. This kind of guarantee unlocks lending to borrowers that advance SDG-related projects but whose risk profile may not be attractive enough for commercial banks to lend money at market rates.

Portfolio guarantees cover a portfolio of loans made by a financial institution to a group of borrowers with pre-established characteristics. These characteristics commonly relate to the sector or SDGs that would be promoted by the guaranteed loan. For instance, a portfolio guarantee could cover loans to SMEs run by women or SMEs in the agricultural sector, with the goal of promoting lending in these two areas.

Portable guarantees cover a specific loan on behalf of a borrower who uses the guarantee to obtain better financial conditions from financial institutions. In this case, the business that obtains the guarantee is able to "shop around" to find a financial institution that is willing to offer it debt at acceptable financial conditions given the guarantee it has obtained.

Source: (African Guarantee Fund, n.d.[14]), https://africanguaranteefund.com; (Private Infrastructure Development Group (PIDG), n.d. [15]), https://guarantco.com

Portfolio guarantees can be extended to local finance providers to encourage lending in a specific sector or type of business. Providers of portfolio guarantees can work either with international financial institutions with presence in developing countries, such as CDC Group who worked with the Standard Chartered Bank in Kenya (CDC Group, 2013 ${ }_{[16]}$ ), or with local institutions, such as Sida working with the Centenary Rural Development Bank of Uganda (Sida, 2016 $6_{[7]}$ ). Portable and loan guarantees, on the other hand, are tailored to a specific lending transaction between a finance provider and a particular borrower. In such cases, finance from local banks is more likely to be mobilised due to the proximity to the customer looking for funding and the relatively smaller funding needs.

\section{Guarantee contracts between a guarantee provider and investors}

Bond guarantees and equity guarantees are different in nature from portfolio guarantees, loan guarantees and portable guarantees as instead of de-risking the lending of financial institutions, they de-risk the financing of capital market transactions by investors. In this case, the guarantee contract does not cover a lending transaction but rather an investment in a business. Institutional investors taking part in these transactions vary and generally include pension funds, high net worth individuals (HNWI), foundations, asset managers and private equity funds. In a similar fashion, balance sheet guarantees aim to de-risk the financial position of a specific business. Bond, equity and balance sheet guarantees are relatively less common although some institutions do use them. For instance, the African Guarantee Fund offers both equity guarantees and bond guarantees (Box 3.4), while GuarantCo and USAID offer bond guarantees. It is noteworthy that these types of guarantees are directly relevant to the development sector. For instance, equity guarantees ensure a long-term commitment to an investment. Bond guarantees require financial 
markets to be relatively advanced and enough demand to exist for companies to raise capital via bond issues. Guaranteeing bond issuances therefore helps to develop the local financial markets, as well as facilitating a corporation's access to finance. Balance sheet guarantees are particularly relevant in the present COVID-19 context, as many companies do not have enough liquidity to face short-term debt obligations. They accounted for 30\% of Sida's portfolio in 2019 (Sida, 2019 [13] $_{\text {) }}$.

\section{Box 1.3. Bond, equity and balance sheet guarantees}

Bond guarantees cover the fundraising of an institution via bond issuance. The guarantee can cover the full bond issuance or (more commonly) the riskiest tranches in the capital increase. These guarantees target specifically institutional investors that are adamant about investing in projects where they perceive the risk to be too high.

Equity guarantees cover the capital investment for equity investors. In comparison with bond guarantees, they can target specific equity tranches to crowd in commercial finance to the riskiest part of the investment. While less commonly issued than the rest of guarantees, equity guarantees ensure an active involvement of the investor and often lead to a long-term partnership between the investor and the business in question.

Balance sheet guarantees cover some of the present financial obligations of an institution experiencing liquidity issues. In the COVID-19 context, these guarantees have been used more extensively given the temporary cash flow constraints of some institutions that are otherwise solvent.

Source: (African Guarantee Fund, n.d.[14]), https://africanguaranteefund.com; (Private Infrastructure Development Group (PIDG), n.d. [15]), https://guarantco.com

There are also other types of guarantees extended to companies with a view to promoting development objectives. Among them are short-term trade guarantees that are used to provide support for companies to engage in import and export activities in the most challenging markets. As indicated by (Mirabile, Benn and Sangaré, $2013_{[1]}$ ), guarantees extended as part of the trade finance programmes (TFPs) usually differ from export-credit guarantees for a variety of reasons: the guarantor agency's mandate is developmental in the former and export-facilitating in the latter, operations are not tied, and most TFP operations involve exports or imports between developing countries (Mirabile, Benn and Sangaré, 2013[1] $)$.

\section{Overview of guarantee providers}

Public institutions issuing guarantees include aid agencies, DFIs, MDBs and export credit agencies. Guarantees extended by export credit agencies are excluded from the scope of this document, as development is not their primary objective and they are largely demand-driven. Further to this, national governments from developing countries can use their sovereign guarantees to back development projects in their own countries, but this is outside the scope of the analysis presented here. The following section presents the key characteristics of each type of providers, briefly explaining institutional benefits and limitations of using guarantees for development at scale. 


\section{Bilateral aid agencies}

Among DAC aid agencies USAID and Sida have the longest track record in issuing guarantees for development. The biggest advantage to guarantees being issued by aid agencies is that bilateral agencies (backed by their sovereign governments) are not obliged to maintain a credit rating and thus can guarantee riskier investments. For instance, Sida's guarantees are sovereign guarantees, which allow Sida's partners to have high levels of confidence in its repayment ability in the event of defaults (Sida, 2017 [11]). USAID's guarantees (issued by USAID's Development Credit Authority until 2019) also fall into the sovereign guarantees category, with the US treasury assuming the full payment of guaranteed obligations. Bilateral guarantee providers (primarily aid agencies, but also bilateral DFIs) have comparatively more freedom to design, structure and price guarantees than multilateral development banks (MDBs), which have more complex internal governance structures. However, whereas DFIs and specialised guarantee providers tend to have greater internal capacity and teams of experts with financial and banking skills, aid agencies often have to rely on external expertise, which may stymie the flow of guarantees. In order to increase the use of guarantees by bilateral agencies, there needs to be an appropriate institutional set up. For instance, Sida collaborates with the Swedish National Debt Office, which is in charge assessing the risks and calculating the guarantees fees. 


\section{Box 1.4. Sida's use of development guarantees}

Background: Sida has been providing guarantees for development purposes for the past 20 years and is one of the market's pioneers. Sida's guarantee instrument is embedded in the agency's operations and is used together with its grants, expertise and partnership instruments in order to obtain the results outlined in the Swedish government's co-operation strategies. Over the last 10 years, the instrument has grown considerably in size. The gross guaranteed amount rose sharply after 2011 and now exceeds SEK 8 billion, at a cost of about SEK 260 million of ODA for subsidies of fees and administrative costs. Currently, Sida's portfolio includes 40 guarantees across 6 sectors, which have mobilised over SEK 21 billion (USD 2.3 billion). The leverage effect of the reported mobilised capital (Sida's share) varies significantly between the transactions, from 1-2 times to 13 times depending on the context and the financial structure.

Sida offers tailored guarantees to institutions across the globe and has the capacity to guarantee large amounts in one single transaction. The largest one is a balance sheet guarantee to the Asian Development Bank (ADB) for the amount of SEK 2 billion (USD 0.2 billion). This guarantee releases headroom in the bank's balance sheet and enables ADB to increase its lending to development projects in Asia with more than double the amount released. This large transaction explains the significant geographical focus regarding guarantee volume to Asia, whereas Africa has the largest number of guarantees. The main thematic areas covered are energy, sustainable infrastructure, and private sector and market development (together accounting for $92 \%$ of Sida's total portfolio).

The Swedish National Debt office assesses the expected loss for each guarantee. Based on the expected loss, Sida charges a guarantee fee to the bank or organisation receiving the guarantee. When necessary, part of the guarantee fee can be subsidised by Sida grants. The expected loss amount including subsidy is paid to the state guarantee service account. The funds from the service account are used for the payments in case of defaults. No other Sida grants are used for the repayment of defaults. Should calls on the guarantee reserve be made in excess of the amount held in the reserve at any time, Sida would have access to an unlimited credit at the National Debt Office.

Business Model: The model provides a high level of financial leverage where only a small portion of Swedish aid appropriation is used to enable high volumes of mobilised capital. At the end of 2019, a total of SEK 260 million of ODA had been spent on subsidising fees and administrative costs across the entire portfolio. During the period 2015-2019, Sida received and compensated 31 claims corresponding to an overall loss rate of $0.1 \%$ on the portfolio. Losses have increased in the past year and are expected to continue to do so, but from very low baseline amounts.

Development Results: Sida has managed to increase access to finance and mobilise additional capital for the SDGs in many of the poorest developing countries at a low cost in terms of claims payment for Sweden as a guarantor. Apart from the direct development results related to access to health products, sustainable infrastructure and access to finance for people living in poverty, the guarantee instrument also allows Sida to foster new partnerships with private financial and real economy actors.

Source: (Sida, 2019[13]), Sida's Guarantee Portfolio, www.sida.se,

https://www.sida.se/contentassets/983246ffbe9641ac880388cf8d6730a9/10204203_quarantee_portfolio_2019_webb.pdf and interview. 
Apart from using sovereign guarantees, bilateral donors may also opt for other models. For instance, since 2019 the Czech Republic has been piloting a funded guarantee programme. In this model, the Czech Ministry of Foreign Affairs provides and reserves funds, whereas the Czech-Moravian Guarantee and Development Bank (ČMZRB) is responsible for the overall management of the guarantee scheme.

\section{Box 1.5. International Development Co-operation Guarantee by the Czech Republic}

Background: In 2017, the Czech government adopted a new Strategy for Development Co-operation (2018 - 2030), which stresses the importance of private sector engagement and encourages the use of innovative tools in support of private finance and investment. A grant B2B programme has been in place since 2014, supporting business partnerships, feasibility studies and technical assistance. This programme has underlined the interest and ability of Czech enterprises to invest in developing markets. More recently, an International Development Co-operation Guarantee (IDCG) has been put in place to compliment the B2B programme. Altogether, the Czech focus on guarantees was inspired by the EU's External Investment Plan and by the national experience of providing guarantees to SMEs. The Ministry of Foreign Affairs provides funding and ensures overall co-ordination and evaluation of the programme, which is managed by the Czech-Moravian Guarantee and Development Bank (ČMZRB).

Business model: The IDCG was launched in 2019 with the aim of supporting private investments in developing countries with high-risk markets. The guarantee instrument covers up to $50 \%$ of the underlying loan, with CZK 50 million as the maximum amount. Investment costs such as purchase and technical improvement of tangible assets and/or acquisition of intangible assets must represent a major part of the total project costs, while operational costs (transfer costs, implementation on site etc.) as a minor part are also eligible. The IDCG is an individual guarantee and each business case is assessed independently. However, the eligibility criteria and the required conditions for the guarantee are standardised (eligible beneficiary, eligible sectors/excluded activities, eligible countries, eligible expenses, guarantee rate, maximum guarantee amount, guarantee period, and guarantee fees). The IDCG is a funded guarantee. For the clients, the guarantee is provided on preferential terms with a guarantee fee of 50 basis points $(0.5 \%$ p. a.).

Development results: The rules of the IDCG programme stipulate that the supported projects must contribute to the sustainable development of partner countries and respect international social and environmental standards. The main development objectives are job creation in productive sectors, training of the local staff, or technology transfer focusing on environmentally viable solutions. The development impact is monitored through a combination of:

- self-assessment of the development impact of the project and affidavit of the client as an indispensable part of the project proposal;

- expert assessment prior to the final approval of the project: reliability of the self-assessment is verified by the Assessment Committee composed of representatives of ČMZRB, the Ministry of Foreign Affairs, the Czech Development Agency and the Export and Guarantee Insurance Corporation;

- monitoring on-site, using the experience of Czech Embassies in the recipient countries.

Source: (Czech-Moravian Guarantee and Development Bank, n.d.[17]), https://www.ecbs.org/banks/czech-republic/czech-moravianguarantee-and-development-bank/view-details.html 


\section{Development finance institutions}

Several DAC donors provide guarantees through their DFIs (including BIO, CDC Group, CDP, COFIDES, FMO, KfW/DEG, Norfund, IFU, OeEB, AFD $1 /$ Proparco, SOFID, USDFC). DFls have diverse governance and financial structures, but are generally majority-owned and financed by their national governments. This governance structure makes it easier for these institutions to secure capital from their respective treasuries and enjoy the creditworthiness needed to raise money in international capital markets. DFIs have "double mandates", i.e. the developmental obligations inscribed in their mission, as well as the imperative to provide financial returns (which brings them closer to pursuing commercial bank business models). While the developmental mandate obligates DFIs to operate in riskier contexts, the second incentivises DFIs to scrutinise project proposals in the same manner as commercial banks (OECD, 2018 ${ }_{[18]}$ ). As compared to bilateral agencies, DFIs have generally larger capacity to deploy development finance and can issue larger guarantees. DFIs also have financial in-house expertise to be able to undertake business and financial assessments of guaranteed projects (including support to project design).

The figure below presents DAC members using guarantees as well as the average amount of private capital mobilised through guarantees over the past eight years. The United States is by far the largest DAC provider of guarantees for development (through both USDFC (former OPIC) and USAID). France, Sweden and the United Kingdom also have significant presence in this field.

Figure 1.1. Amounts mobilised by guarantees by DAC providers, 2012-18 average, USD thousands

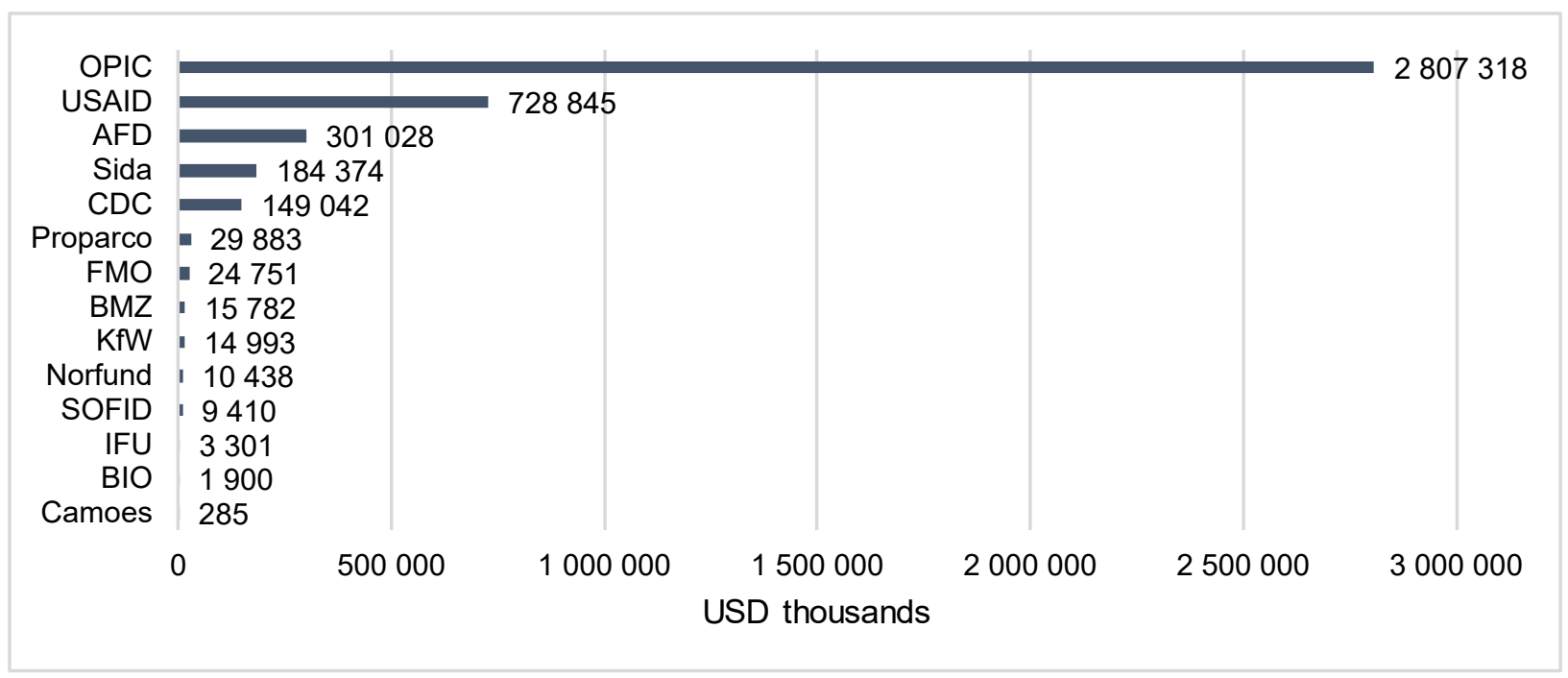

Source: (OECD, n.d.[19]), Amounts mobilised from the private sector for development, http://www.oecd.org/development/stats/mobilisation.htm

\section{Multilateral development banks}

Since the 1980s, guarantee schemes have been set up in all the major MDBs and their use has been slowly growing (Humphrey and Prizzon, 2014 ${ }_{[2]}$ ). In part, this is due to the fact that guarantees hold distinct advantages, such as targeting specific classes of risk and helping to 'crowd in' other funding sources. This is particularly relevant in view of the strong call by the international community to mobilise more private resources for development (OECD, 2018[18] $)$. Currently, guarantees are issued by all the major MDBs, including the World Bank Group, the Inter-American Development Bank (IDB), the European Bank for Reconstruction and Development (EBRD), the Asian Development Bank (ADB), and the African Development Bank (AfDB). Yet, guarantees still only represent a fraction of their portfolios. For example, in 2018, guarantees represented $8 \%$ of the EBRD's commitments, around $4 \%$ of the IFC's, and $2.9 \%$ of 
the IBRD's commitments (Bandura and Ramanujam, 2019 $\left.{ }_{[3]}\right)$. The World Bank Group is the largest development guarantee provider in the world, using three different arms (MIGA, IFC and IBRD/IDA) to provide different types of development guarantees.

\section{Box 1.6. Multilateral Investment Guarantee Agency's political risk insurance and credit enhancement}

Background: The Multilateral Investment Guarantee Agency (MIGA) was established in 1988 through an international convention, as the newest member of the World Bank Group. MIGA was created to complement public and private sources of investment insurance against non-commercial risks in developing countries. MIGA's multilateral character and joint sponsorship by developed and developing countries were seen to significantly enhance confidence among cross-border investors. Today, MIGA's mission is to promote foreign direct investment (FDI) into developing countries to support economic growth, reduce poverty and improve people's lives. At the end of Fiscal Year 2020, MIGA's portfolio consisted of USD 22.6 billion in gross outstanding guarantees, supporting 195 projects.

Business Model: MIGA promotes FDI in developing countries by providing guarantees (political risk insurance and credit enhancement) to investors and lenders. MIGA's guarantees protect investments against non-commercial risks and can help investors obtain access to funding sources with improved financial terms and conditions. MIGA complements official export credit agencies and private providers of political risk insurance and credit enhancement. The Agency derives its unique strength from the World Bank Group and from its structure as an international organisation whose shareholders include most countries in the world. This enables MIGA to provide an umbrella of deterrence against government actions that could disrupt projects, and assist in the resolution of disputes between investors and governments. MIGA also adds value through its ability to offer clients extensive knowledge of emerging markets and of international best practice in environmental and social management. Premium rates are decided on a per-project basis and vary by country, sector, transaction and the type of risk insured.

Development Results: MIGA's development impact system operates throughout the project lifecycle. At inception, all projects supported have an ex-ante assessment undertaken of the expected development impact through the Impact Performance Assessment and Comparison Tool (IMPACT). During monitoring, each project's development outputs are collected, and each project is ultimately evaluated in detail once it has reached operational maturity. Between fiscal years 2014 and 2020, MIGA supported projects are expected to provide access to power for 62 million people, provide 120000 jobs, generate USD 4.1 billion in tax revenue for host governments and avoid 10.4 million metric tons of greenhouse gases.

Source: (Multilateral Investment Guarantee Agency, n.d.[20]), https://www.miga.org/ and interview.

The remits of MDBs reflect the development co-operation priorities and interests of the multiple states that are their shareholders. MDBs' close relations with governments often have positive, yet intangible, effect (dubbed the "halo effect" by S\&P) of increasing the comfort of private investors to enter into a transaction (Humphrey and Prizzon, 2014[2]). MDBs' high ratings may also have a significant impact on the financial terms offered to a borrower thanks to a guarantee (i.e. lower interest rates or extended maturities). However, as MDBs' business models and stakeholder expectations require them to maintain AAA credit ratings, they tend to be essentially more conservative than bilateral DFIs when it comes to risk (Bandura and Ramanujam, 2019 ${ }_{[3]}$ ). 


\section{Specialised guarantee providers}

Guarantees are also used by specialised providers, such as GuarantCo, InfraCredit or the African Guarantee Fund (AGF). Such specialised institutions pursue a dual mandate of both development impact and financial returns. Specialised providers are generally owned and capitalised by multilateral or bilateral organisations and strive to be financially sustainable. They usually obtain ratings by credit rating agencies and can pass on their credit rating to the guaranteed portion of an investment. However, in some cases this can lead to a more conservative approach regarding guarantee provision, as specialised providers want to maintain their ratings. Certain providers, such as GuarantCo and the AGF actively seek to attract private investors. They are also able to borrow money in international financial markets and therefore increase the size of their balance sheet. Specialised providers do not use rules intended for regulated financial institutions when accounting for guarantees and can make greater use of unfunded guarantees and leverage their balance sheet (Bandura and Ramanujam, 2019 $9_{[3]}$ ).

\section{Box 1.7. Guarantees by GuarantCo}

Background: GuarantCo is the guarantee arm of the Private Infrastructure Development Group (PIDG) and was established in 2005 to help mobilise local currency financing into domestic infrastructure in developing countries and thereby promote local capital market development. GuarantCo is funded by the governments of the United Kingdom, the Netherlands, Switzerland, Australia and Sweden and is rated by Fitch (AA-) and Moodys (A1). It has provided guarantees in over 22 countries across 9 infrastructure sub-sectors and has a current portfolio of around 800 million USD, of which over $80 \%$ represents local currency guarantees.

Business Model: GuarantCo approaches each transaction through a problem-solving lens and assesses how a guarantee can be designed to provide the solution. Consequently, its guarantees are typically bespoke in structure, albeit with some homogeneity in terms of (i) covering the non-payment risk of a project irrespective of the reason for non-payment (i.e. the guarantee can cover non-payment for both commercial and political reasons), and (ii) allowing GuarantCo the choice of paying the beneficiary either in full or in instalments. GuarantCo adopts a transaction-specific approach to pricing and seeks to balance commercial returns and development impact. The average guarantee fee across GuarantCo's existing portfolio is approximately $3 \%$, typically charged on a per annum basis. Partnering effectively with local private sector participants has underpinned GuarantCo's success over the past 15 years in delivering over 55 transactions and paving the way for several market innovations.

Development Results: GuarantCo uses a balanced scorecard approach to evaluate the development results (also referred to as the "impact") of transactions. The scorecard, used across the PIDG Group, assesses the impact of a transaction on (i) people and planet, (ii) the wider economy, (iii) the mobilisation of private investments, and (iv) the ability to transform the market. This approach ensures that all transactions contribute to the SDGs, align with PIDG's strategic priorities and have demonstrable financial and development additionality. Since 2005 GuarantCo-supported transactions have generated significant development impact and have cumulatively provided improved access to infrastructure for 43 million people, created 235000 jobs, and enabled USD 5.6 billion of investments.

Source: (Private Infrastructure Development Group (PIDG), n.d.[15]), https://guarantco.com 


\section{Renewed interest in the use of guarantees for development}

The most significant entrant to the development guarantees market in recent times is the European Fund for Sustainable Development (EFSD). As part of the European Union's External Investment Plan, this fund was launched in September $2017^{2}$. The management of the EFSD guarantees, which have a total budget of EUR 1.5 billion, can only be extended to entities assessed by the European Commission and who can thus be entrusted with EU resources. At present, "pillar-assessed" entities for the EFSD guarantees include European financial institutions (such as the EIB and the EBRD), bilateral development banks and development finance institutions in the EU Member States (such as the AFD, CDP, FMO, DEG, COFIDES), as well as other multilateral financial institutions/development banks (such as the IFC and the AfDB). Given the early stages of the EFSD implementation, it is not possible to assess the effectiveness of EFSD guarantees. However, it is important to note that the EFSD has already incentivised and enabled the widespread engagement of European financial institutions ${ }^{3}$ in using guarantees for development purposes (i.e. implementing EU budget guarantees for external action), and several other EU member states (such as the Czech Republic and Poland) are considering moving into this sphere. The EFSD guarantee model is set to be expanded under the EU's 2021-2027 development budget. This is currently under negotiation, but, if approved, it may further encourage the use of guarantees among EU member states.

\section{Box 1.8. European Fund for Sustainable Development}

Background: The European Fund for Sustainable Development (EFSD) is currently the EU's main financial instrument to promote investment in countries in Africa and the EU neighbourhood. For the first time, it offers the EU the opportunity to provide a budgetary guarantee to share the risk of investing and lending in these countries. The European Commission has proposed to bring the guarantee capacity to scale and go global in the next funding cycle.

Business model: The EU's budgetary guarantee of 1.5 billion EUR is provisioned at $50 \%$ with a cash contribution stemming from ODA resources (750 million EUR). The European Commission manages the EFSD and invited its partner financial institutions (European and international development banks) to propose investment programs in pre-defined priority areas. These programmes should demonstrate the additionality of EU support - i.e. contribute to sustainable development through operations which otherwise would not take place or achieve positive development results above and beyond what could have been achieved without the guarantee. Financial additionality means crowding in private sector funding and addressing market failures or sub-optimal investment situations, while development additionality refers to improving the quality, sustainability and development impact of an investment. The programmes should also be complementary to ongoing EU actions, be sustainable and bankable, provide adequate risk sharing among prospective partners to ensure the alignment of interest, respect the Busan Aid Effectiveness Principles and OECD-DAC criteria for ODA, and be implemented in line with the agreed international conventions.

The EFSD guarantee is flexible with a focus on private (co-) investors. It can be deployed as first/ second/third-loss guarantees, credit enhancement, junior equity, securitisation, as well as provide specific risk cover for PPAs or construction phases, amongst others. The guarantee is priced, so the PFIs pay a premium to use it. Market distortion should be avoided. Pricing is based on the expected loss of the underlying risk; unexpected loss premium and administration costs are waived. The European Commission can decide to provide a discount on the fee and make it preferential for operations in countries identified as experiencing fragility or conflict, LDCs and heavily indebted poor countries, and for special target groups such as youth, women, and migrant entrepreneurs. The guarantee is part of the EU External Investment Plan, and it complements the blending projects, technical assistance and investment climate support which the Plan also provides. 
Status and results: To date, the EU has agreed on guarantee proposals worth a total of 1.54 billion EUR. These should leverage 17.5 EUR billion in investment and create up to 4 million jobs. The Commission has so far signed agreements for eight guarantees and expects to conclude all agreements in 2020. The EFSD Guarantee is part of the EU's response to the COVID-19 pandemic - its support is re-oriented to help partner countries address the socio-economic impact and continue to deliver vital health services. It does so by providing access to loans and guarantees, despite the crisis-situation, and by supporting the private sector through loan guarantees, technical assistance and increased access to liquidity support, working capital and trade finance.

Source: (European Commission, 2020[9]]), Implementation Report of the EFSD and the EFSD Guarantee, https://ec.europa.eu/commission/sites/beta-political/files/efsd-implem_report-external_support_study-final.pdf 


\section{Key benefits and limitations to using guarantees for development at scale}

Guarantees, as a blended finance tool, are uniquely suited to facilitate investment flows to developing countries and high-risk sectors and have the potential to mobilise additional resources beyond what financial markets would normally provide (Mirabile, Benn and Sangaré, 2013[1]). Apart from their ability to mobilise private finance, their key advantage is that they allow for the optimisation of public resources used for development. Guarantees are customisable and therefore flexible, serving a variety of development purposes: they can back-stop high-impact investments in risky markets, de-risk a local bank's loan portfolio for small and medium enterprises (SMEs) or transfer risks from local financial institutions to service underserved borrowers.

Despite their potential, so far guarantees have not been used at scale as a blended finance tool. A DAC agreement on the ODA-eligibility of guarantees could make the incentive for using guarantees significantly stronger (See Chapter 5). As shown in the bilateral consultations conducted as part of this research, another key challenge for scaling up the use of guarantees is linked to the fact that deploying guarantees requires specific financial and risk management expertise which might not be readily available in DAC members' aid agencies. Consultations also indicated that both awareness and the evidence base about the use of guarantees for development purposes is limited. There are also disincentives for MDBs linked with accounting rules, as well as limited data available about development impact of guarantees. Other obstacles to using guarantees at scale are linked to the limited pipelines of bankable projects and supplyside constraints, especially in least developed markets, scarce data regarding appropriate pricing of such instruments in these markets, as well as complexity in structuring guarantees (especially if guarantee contracts include several guarantors and lenders with various preferences, risk appetites and objectives). In what follows, the document presents in more detail key advantages of guarantees, as well as limitations to their widespread and effective use.

\section{Rationale for using guarantees for development and their benefits}

\section{Mobilisation of private finance}

Guarantees are a particularly valuable instrument for mobilising private resources for development purposes. As shown by the OECD data on amounts mobilised from the private sector by official development finance interventions 2012-2018, guarantees mobilised more private capital than direct lending or equity investments (OECD, 2020[21]). 


\section{Box 2.1. Measuring private finance mobilised by guarantees}

As demonstrated by the OECD data, guarantees have the potential to mobilise large amounts of private capital. The DAC-agreed methodology on mobilisation measures the amounts mobilised by guarantees as "the full nominal value of the instrument (e.g., loan, equity) to which the guarantee relates, regardless of the guarantee's coverage" $\left(\mathrm{OECD}, 2020_{[21]}\right)$. In the case of co-guarantees, the private finance mobilised is attributed to all official guarantors, pro-rata according to the amount guaranteed by each. A different methodology on mobilisation is used by MDBs, which accounts for the guarantee's exposure to the project (i.e. the covered portion of the underlying investment). Nevertheless, for the purpose of the DAC statistics, MDBs have also agreed to present the mobilisation effect of their guarantees following the same approach on development finance. A joint MDB - OECD DAC working group on measuring mobilisation has been established to further harmonise the methodologies and address the confidentiality constraints faced by the MDBs when reporting to the OECD on their mobilisation effect.

Source: (OECD, 2020[21]), DAC methodologies for measuring the amounts mobilised from the private sector by official development finance interventions, https://www.oecd.org/dac/financing-sustainable-development/development-finance-standards/DAC-Methodologieson-Mobilisation.pdf

The amount of private finance mobilised by guarantees has increased steadily over the past six years, from USD 8 billion in 2012 to over USD 18 billion in 2018, equivalent to an annualised growth rate of $14 \%$. In fact, guarantees have mobilised more private finance than any other financial instrument, representing $39 \%$ of total private finance mobilised for development over the period covered by the data. While the yearly percentage of private finance mobilised by guarantees has slightly decreased, this is due to the faster growth of other instruments. Moreover, guarantees have been the most effective tool to mobilise capital in every year for which data is available.

Figure 2.1. Amounts mobilised by year and instrument 2012-2018

\section{Amounts mobilised by year and instrument, 2012-18}

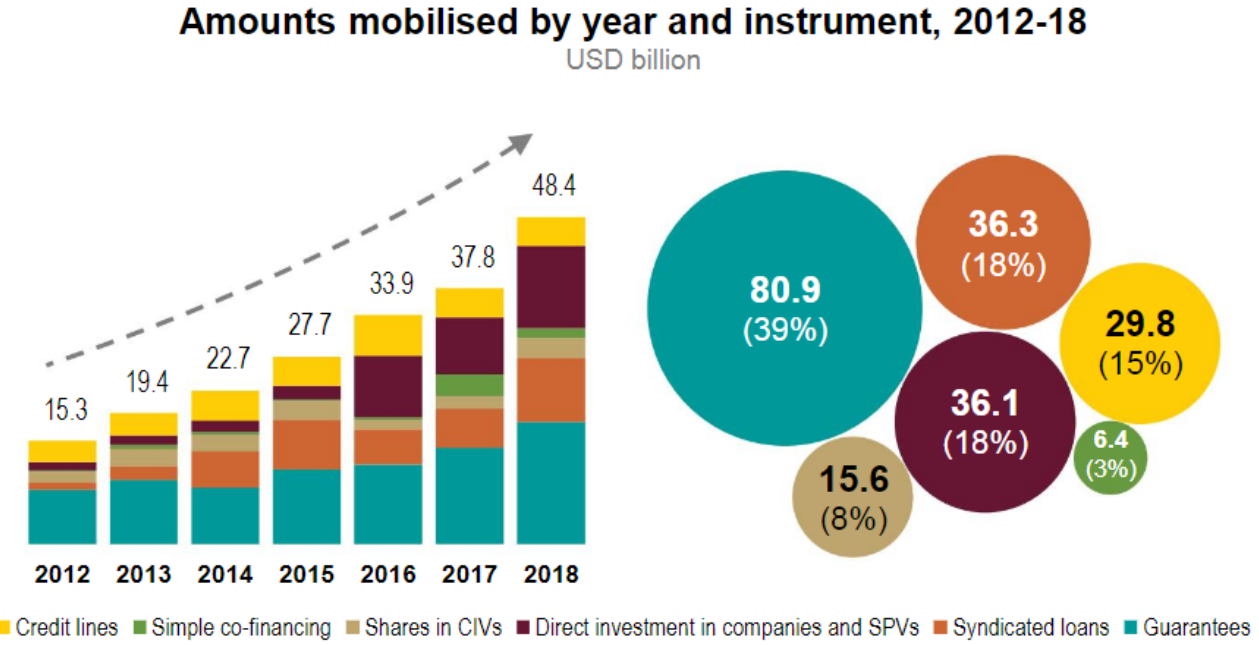

Source: (OECD, n.d.[19]), Amounts mobilised from the private sector for development, http://www.oecd.org/development/stats/mobilisation.htm

Following the same trend as other blended finance instruments, the largest share of private finance was mobilised by guarantees in middle-income countries (MICs) and revenue-generating sectors (such as 
banking, financial services and energy sectors). Meanwhile, LDCs and other LICs accounted for only 5.3\% of private finance mobilised. In terms of sectoral distribution, agriculture or healthcare accounted for a marginal share of mobilisation (around 2.2\% in total). Yet, as shown by 2017-2018 data, guarantees were also the main leveraging instrument in Africa, representing $39 \%$ of total private finance mobilised by all official interventions to this continent, and were used to finance projects across different sectors, including social infrastructure. Taking into account the potential of guarantees to be used across different sectors and geographies, it is important to analyse new ways to incentivise private capital to flow into the most fragile countries and underserved sectors.

\section{Figure 2.2. Amounts mobilised by region, 2017-2018 average}

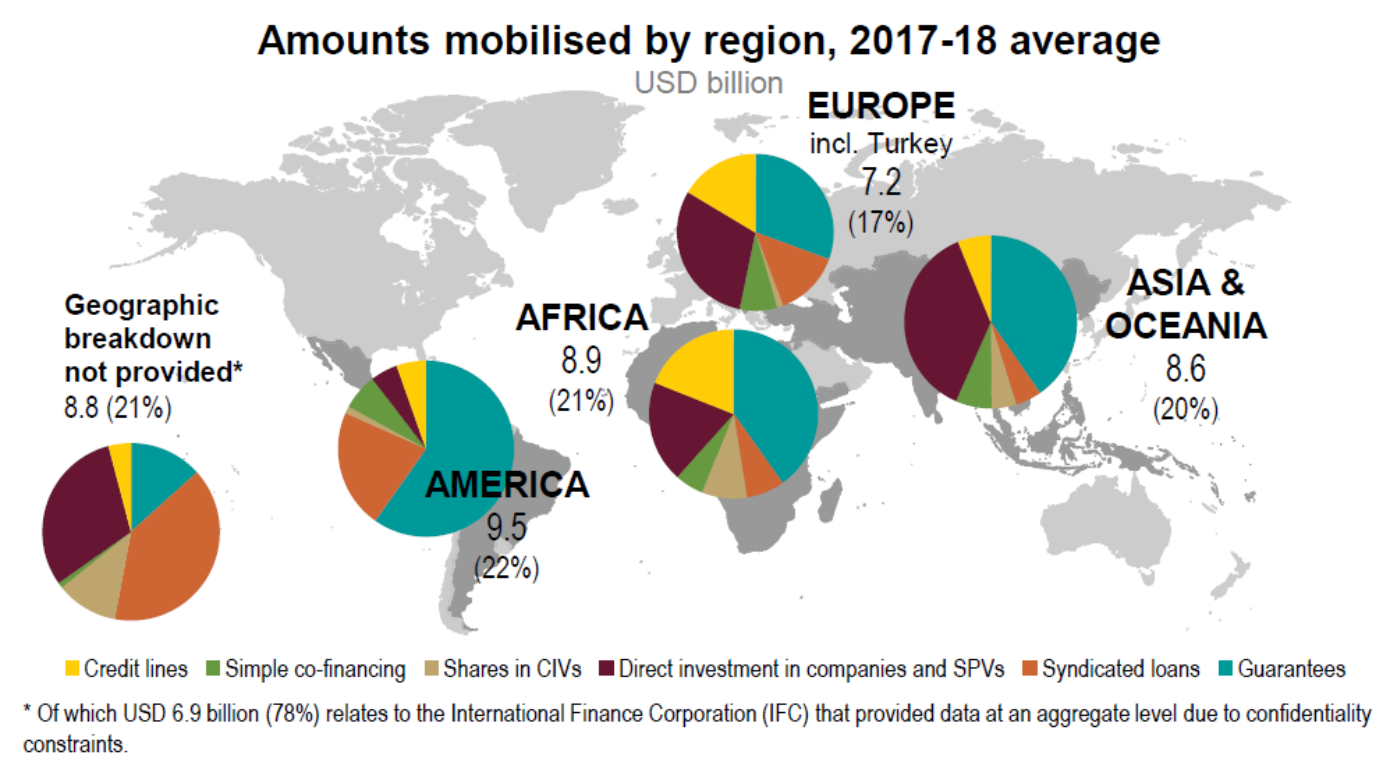

Source: (OECD, n.d.[19]), Amounts mobilised from the private sector for development, http://www.oecd.org/development/stats/mobilisation.htm

\section{Box 2.2. Mobilisation vs. leverage ratio of guarantees}

It is important to distinguish between mobilisation and leverage. The amount mobilised by guarantees shows how many resources were made available due to the use of the instrument, while the leverage ratio indicates the amount of resources employed (by the official sector) to the amount of resources mobilised. It should be emphasised that the leverage ratio has never been used by the DAC to present the mobilisation data, as it could set the wrong incentives for donors (e.g. focus on MICs where mobilisation is easier). Moreover, for guarantees, measuring the amount of resources employed ("the donor effort") it not straightforward, as the public institution (or donor) effort is not immediately clear in the form of a discrete payment. There are several variables that could be taken into consideration when accounting for "the donor effort". A detailed discussion of this issue is available in (Mirabile, Benn and Sangaré, 2013[1] . 


\section{Additionality}

Guarantees for development are often used to improve access to finance and alleviate credit restrictions for underserved borrowers (e.g. allowing for lower rates, longer tenors, decreased collateral demanded) or to improve the general financing conditions of underlying instruments (Hansen, Rand and Winckler Andersen, 2020[6]). In this sense, if the entity receiving the guarantee would not have been able to access finance without a guarantee, this instrument brings financial additionality.

\section{Box 2.3. Additionality - definitions}

In the context of reporting on private sector instruments in the OECD statistics, an official transaction is considered additional either because of its "financial additionality" or "value additionality", combined with its "development additionality".

Such a transaction is financially additional if it is extended to an entity which cannot obtain finance from the private capital markets (local or international) with similar terms or quantities and for similar developmental purposes without official support, or if it mobilises investment from the private sector that would not have otherwise invested. Financial additionality aims to avoid market distortion, i.e. institutions do not compete with other commercial finance providers, but rather support capitalconstrained markets, and, where possible, crowd in investments.

It is additional in value if the official sector offers to recipient entities or mobilises, alongside its investment, non-financial value that the private sector cannot or does not offer, and which will lead to better development outcomes, e.g. by providing or catalysing knowledge and expertise, promoting social or environmental standards or fostering good corporate governance.

It conveys development additionality if the development impact of the investment would not have occurred without the partnership between the official and the private sector.

Source: (OECD, 2021 $\left.{ }_{[22]}\right)$, Converged Statistical Reporting Directives for the Creditor Reporting System (CRS) and the Annual DAC Questionnaire: Reporting methods for private sector instruments (Annex 23),

https://one.oecd.org/document/DCD/DAC/STAT(2020)44/ADD3/REV2/en/pdf

Guarantees can also bring development additionality if they lead to development impact that would not have occurred without the use of this instrument (e.g. credit access for refugees and women entrepreneurs, new jobs created, etc.). Certain publicly supported guarantee schemes that target underserved market segments may also bring value additionality by improving the provision of market information that was previously unavailable. For example, as shown by the NASIRA Risk Sharing Facility, guarantee programmes that target local financial institutions in LDCs may allow for gathering and building credit data on populations that have been traditionally been underserved (such as refugees and migrants) and for which such data did not exist (European Commission, 2019[23]). Guarantee contracts can also be used to ensure the inclusion of safeguards, good corporate governance and foster more socially responsible businesses. However, it bears emphasising that more rigorous evidence on donor-backed guarantee schemes is needed to ascertain how final beneficiaries benefit from the development additionality of guarantees. 


\section{Flexibility}

There are considerable variations of guarantees in terms of their set up, use and type and they can be tailored to the particular requirements of a given project, lender and/or borrower. As indicated earlier, guarantees are highly customisable as a development finance instrument and have been successfully used in a variety of contexts by bilateral donors (both aid agencies and DFIs), MDBs and specialised guarantee providers. By using different types of guarantees, donors can achieve specific aims and design the right incentive structures for the private sector. For example, to ensure the maximisation of the crowding-in of commercial finance to facilitate investments in developing countries and high-risk sectors, donors can choose to provide first-loss guarantees in which the burden from defaults is fully assumed by the guarantor (up to a predetermined tranche of losses), or design guarantee products with high coverage ratios. In this way donors can increase the risk-return profile of high impact investments and catalyse the participation of investors that would not have otherwise participated. In order to incentivise the private sector to invest without necessitating excessive risk-taking by donors, partial guarantees can offer a solution as they ensure that borrowers/investors retain "skin in the game" i.e. they are directly involved and share the risk. This can be achieved by issuing guarantees that cover only a portion of the financing or one type of risk. Guarantees can be continually revised with regards to their pricing and length, financing component covered and adjusted conditions in order to ensure that the private sector is incentivised to deliver the project throughout its lifetime.

\section{Optimising resource allocation}

Since unfunded guarantees are contractual obligations to repay loans only in case of default, and since they entail relatively low initial costs, in the current COVID-19 context where donor governments are resource-constrained, guarantees offer a solution for most effectively leveraging guarantors' balance sheets. The instrument also allows for the covering of a portion of the risk exposure of a deal/transaction, which may be sufficient to unlock additional financial resources for development-oriented investments.

\section{Limitations to using guarantees for development}

\section{ODA eligibility of guarantees}

Under the current Provisional Reporting Arrangements for Private Sector Instruments agreed by the DAC in 2018, individual guarantees are not ODA-eligible except to the extent that guarantees are called and payments are made, in which case payments are measured on a cash flow basis (OECD, 2021 [22]). However, the arrangement allows donors to report as ODA capitalisations of DFIs and other PSI vehicles ${ }^{4}$ that provide guarantees (at the point of transfer of funds to the vehicles). A modernised PSI reporting system could create stronger incentives for increasing the use of guarantees - and by extension boost efforts to scale up engagement by the private sector in development finance (this is discussed further in Chapter 5).

\section{Complexity in structuring guarantees and the need for expertise}

Guarantees are complex instruments to structure, especially when a guarantee contract includes several guarantors and lenders with various preferences, risk appetites and objectives. Compared to debt instruments, guarantees add complexity by including a third party; instead of a lender and a borrower, guarantees add a guarantor, which protects the lender against a potential default by the borrower. This implies expanded due diligence and a larger amount of legal and regulatory requirements. Investment guarantees require projects to be relatively advanced, whereas equity financing can be used at earlier stages of project development to build and structure projects. Currently, the lack of standardisation among 
guarantee products across development finance providers can lead to more time being spent on negotiations by the parties involved in a deal, as well as high transaction costs (e.g. legal costs) (GIIN, $2017_{[24]}$ ). The complexity of guarantees has implications for the skill-set needed within development organisations who want to develop and issue guarantees. According to (Lee, Betru and Horrocks, 2018[4] ), many development organisations lack the operational capabilities to provide guarantees at scale. Commercial skill sets and financial backgrounds are exceptions rather than the rule in many development organisations, and building such capabilities in order to deliver best practices requires proper training and incentives for development institution personnel.

\section{Disincentives for multilateral development banks}

It has been argued that MDBs face a number of impediments to using guarantees at scale, which are linked to their capital structure, financial and operational policies, as well as staff skill sets (Lee, Betru and Horrocks, 2018[4]) (Humphrey and Prizzon, 2014[2]). Several studies, including the ODI report by (Humphrey and Prizzon, 2014[2]) and a CSIS study by (Ramanujam Bandura, 2019 ${ }_{[25]}$ ) argue that MDBs are constrained by their internal accounting rules which require them to provision guarantees in the same way as they would provision direct loans, even though guarantees are not funded and rarely called. This disincentive is linked with the fact that rating agencies' performance metrics for MDBs encourages MDBs to act like commercial banks and focus on direct lending rather than guarantee-backed blended financing (Lee, Betru and Horrocks, 2018[4] $)^{5}$

There are also external factors that may work to disincentivise the use of guarantees by banks adhering to international regulations. The international regulatory frameworks introduced by the Basel Committee on Banking Supervision (Basel regulations) require banks to hold a minimum amount of high-quality liquid assets (HQLA) to cover expected cash outflows. These requirements will become stricter once Basel IV is fully phased in. However, SDG-aligned investments covered by guarantees do not currently qualify as HQLA and this will reduce banks' appetite for originating such illiquid exposure. To counteract this effect, guarantees would need to adapt their structure to HQLA requirements to ensure the guaranteed project can be considered HQLA. For instance, this could mean improving their transferability and tradability (Lee, Betru and Horrocks, 2018[4] $){ }^{6}$

\section{Measuring development impact of guarantees}

Impact goes beyond the immediate results of an intervention and refers to its "transformative effects" (OECD, 2019 $\left.{ }_{[26]}\right)$. The OECD defines impact as "the extent to which the intervention has generated or is expected to generate significant positive or negative, intended or unintended, higher-level effects" (OECD, $2019_{[26]}$. As mentioned earlier, guarantees have proven to mobilise relatively large amounts of private finance for development purposes and create financial additionality (Saadani, Arvai and Rocha, 2011 [27]) (Boocock and Mohd Shariff, 2005 ${ }_{[28]}$ ) (Huidobro and Reyes, 2014 ${ }_{[29]}$ ). Consequently, guarantees have the potential to generate large-scale development effects. The cases presented in this paper demonstrate that guarantees are used for (and achieve) a variety of development objectives, such as improving access to finance, enhancing lending to underserved borrowers, and mitigating the risks of investment. Yet, while it is considerably easier to determine the immediate results of guarantees (for instance a volume of new investments unlocked by a guarantee or a number of entities with enhanced access to finance), it is more difficult to ascertain and measure their long-term development impact. This would include e.g. the contribution of a guarantee scheme towards poverty reduction, job creation or providing decent and stable livelihood opportunities for end beneficiaries. Given the lack of common vocabulary among development finance actors, it is possible that, while organisations using blended finance interventions claim to measure impact, they may sometimes conflate it with outcome or even output (Basile, Bellesi and Singh, 2020[30]). Moreover, in complex blended finance schemes, transparency often decreases along the delivery chain as the complexity of governance patterns affect monitoring and evaluation (Winckler Andersen et al., 
$2019_{[31]}$. As indicated in a recent report of Danida that reviews several evaluation studies of guarantees, evidence on guarantees' development impact is mixed and more rigorous data is needed in that regard (Hansen, Rand and Winckler Andersen, 2020[6] ). As shown earlier in this paper, some guarantee providers have already developed impact measurement tools, such as MIGA's Impact Performance Assessment and Comparison Tool (IMPACT) or GuarantCo's score card system. In order to establish a strong evidence base on the development impact of guarantees it is crucial that guarantee providers establish adequate impact management and measurement systems that are applicable to guarantee schemes.

\section{Limited pipelines of bankable projects}

The use of guarantees is demand-driven and their successful application depends on the existence of that demand (Sida, 2016 $\left[\mathrm{r}_{]}\right)$. In developing markets, private investments are often limited because of lack of bankable projects. In some cases, projects that can potentially generate development impact may fail to achieve financing on market terms because they are considered too risky by commercial investors. Risk mitigation or credit enhancement schemes may help viable projects (that are not yet considered bankable) receive financing. In sectors that have high operating costs, low returns and are constrained by access to finance, such as agriculture, traditional loan guarantees may not be enough to overcome barriers to lending (Aceli Africa, 2020[32]). In order to overcome this barrier, some organisations, such as Sida, USAID/DCA and the European Commission, have combined guarantees with technical assistance and advisory services (Sida, 2017[11]) (European Commission, 2019 ${ }_{[23]}$ ). While this requires additional resources and specific project knowledge, it can reassure investors of the potential returns to their investment and increase the bankability of projects. By providing project development and financial advisory support alongside guarantee contracts, donors can assist local financial institutions to make more extensive and better use of risk mitigation instruments, and also to appropriately price risks.

\section{Supply-side constraints}

Donor-backed credit guarantees cannot themselves overcome the problems inherent to supply-side bottlenecks related to the beneficiary institutions' performance, such as their risk management approaches, the lack of reliable data on beneficiaries, or inadequately designed projects. These challenges may be more acute in developing countries, particularly the LDCs, where financial institutions and systems are less developed. Additionally, for guarantees to succeed, a conducive regulatory environment and a sound legal framework must exist. For instance, credit guarantee contracts require "legal certainty" and close co-operation among guarantors and financial institutions in the process of accepting guarantee claims, disbursements, controlling the use of loan capital, and recovering debts (Dang Le Ngoc Chuc Anh $\left.\mathrm{Tu}, 2019_{[33]}\right)$. Thus, guarantees cannot compensate for an unconducive environment. Another precondition for the success of a guarantee scheme is its "localisation", i.e. guarantees have to be tailored to the local market conditions, both the financial market as well as the conditions in the targeted geographical area. Furthermore, the successful implementation of donor-backed guarantees, especially political risk guarantees, is also conditioned on donor relations with beneficiary governments. For example, IBRD/IDA guarantees require a counter-guarantee on the part of the host government, creating a direct contractual link with the host country relating to the project ${ }^{7}$, while MIGA requires host country approval before issuing a guarantee (World Bank Group, 2016[34]).

\section{Limited awareness and availability of guarantees}

Due to a relatively limited usage of guarantees for development until recent years, there is little awareness of their availability and the benefits they can provide as a development finance tool (World Bank, $200{ }_{[8]}$ ) (GIIN, 2017[24]). From the donor side, grants and direct lending have been the traditional instruments used in the development context. From the beneficiaries' side, lack of knowledge regarding the availability of guarantees prevents many borrowers from trying to access credit. Capacity building and promoting the 
wider dissemination of information on the availability of guarantees can be key to increase their use, particularly in underserved areas where the use of guarantees has so far been even more limited.

\section{Pricing of guarantees}

A lack of information in underdeveloped markets may affect guarantees' pricing models. Guarantees are easier to structure in more developed capital markets, where risks are better priced, whereas in countries with underdeveloped financial markets it may be difficult to determine what the market rates are. By incentivising private capital to invest in underdeveloped markets, guarantees can help to re-adjust the risk perception of such investments and incentivise private capital to invest at newly determined market rates. Once commercial investors have experience in that area, it is likely that their risk perception will be reduced. When a guarantee contract is in force, the risks can decrease over the life of the transaction. Guarantee schemes could potentially have adjustable ratios and pricing to accommodate learning in the financial market (Hansen, Rand and Winckler Andersen, 2020[6]).

\section{Box 2.4. Different approaches to the pricing of development guarantees}

The pricing of development guarantees varies as each providing institution applies its own pricing models. Each approach is based on the capacities and specific needs of each provider and is suitable for that particular context. For instance, as discussed earlier, Sida collaborates with the Swedish National Debt office to determine the pricing of its guarantees based on individual transactions' probability of default. CDC calculates the premiums internally. Based on risk-sharing proportions, CDC splits the net credit margin between the local bank's cost of capital and its gross margin for the project. MIGA takes into account both country- and project-specific characteristics when deciding the fees to charge (which average approximately $1 \%$ per year). On the other hand, the AGF's fees vary significantly across different types of guarantees and are comprised of a facility fee and a utilisation fee. Certain institutions, such as the European Commission, as in case of the EFSD Guarantee, subsidise the guarantee fee in order to make the pricing affordable for the guaranteed party.

Source: (Sida, 2019 $\left.9_{[13]}\right)$, (www.cdcgroup.com, n.d.[35]), (Multilateral Investment Guarantee Agency, n.d.[20]), (African Guarantee Fund, n.d.[14]), (European Commission, 2020[9])

\section{System-level considerations: debt sustainability}

As guarantees relate predominantly to debt instruments (loans taken by private and public entities), their increased use has implications for debt levels in developing countries. In the context of the economic crisis triggered by the COVID-19 pandemic, some developing countries are currently in debt distress and could also face the danger of private debt build-up. Furthermore, as the need for additional fiscal space to tackle COVID-19 and its economic fallout continues to grow, the developing countries' capacity to take on additional lending is decreasing. Debt sustainability is a system-level consideration that donors have to take into consideration while using all types of debt instruments in their bilateral programmes, including guarantees ${ }^{8}$ (OECD, 2020[36]). Some have argued that, in response to the COVID-19 crisis, donors could consider prioritising grant-based financing as the default option, especially in LDC contexts. Yet, it also bears remembering that some donors in fact decided to scale up their use of guarantees as part of their first responses to the COVID-19 crisis, specifically to mitigate any default risks and focus on guaranteeing existing portfolios of loans (as opposed to generating new ones). ${ }^{9}$ 


\title{
How can guarantees be used to specifically target the least developed countries and underinvested sectors?
}

\begin{abstract}
Despite widespread efforts, many developing countries, including the LDCs, are falling behind in the scaling-up of finance for development. This impedes their ability to deliver on critical development objectives. Although guarantees have traditionally disproportionately targeted middle-income countries, as indicated earlier, they have also proven to be a key instrument for mobilising private finance in Africa. From 2012-18, guarantees were used to mobilise private finance in 35 LDCs. ${ }^{10}$ Even though there remains a substantial variation between individual countries in the LDC category, in general these countries suffer from underdeveloped capital markets and poor regulatory, legal and tax frameworks, as well as inadequate or unavailable financial information. In such contexts, the demand for risk mitigation solutions, including guarantees, is increasing. Currently, with high levels of public debt and the additional pressures on all sources of development finance caused by the COVID-19 crisis, LDCs are struggling to finance their public health, social and economic responses to COVID-19 (OECD/UNCDF, 2020[37]), and guarantees have already featured in donor policy responses to the crisis.
\end{abstract}

The remainder of this section explores different ways in which guarantees can help promote investment and lending in underserved geographies. Guarantees have been used as an instrument for supporting local financial markets, for example by facilitating a local-currency bond issuance. Guarantees are also used to de-risk large-scale infrastructure projects, as they can be tailored to specific risks, such as construction period risk, and they also play an important role in mitigating political risks. They are uniquely suited to de-risking pioneering investments in markets where the risk perception of investors does not reflect reality. Yet, during the consultations in preparation of this paper, concerns have been raised that the increased use of guarantees by donors could lead to a further push towards the privatisation of public services in developing countries. ${ }^{11}$

\section{Spurring local currency financing and domestic resource mobilisation in the LDCs}

In many LDCs, there is a need to deepen domestic financial markets and increase market liquidity. Across many of the countries in the LDC bracket, hard currency financing is still the norm, despite there being very limited options for the market-based mitigation of exchange-rate risk. There is a growing body of evidence indicating that the development of local currency bond markets can strengthen the stability of local financial systems in the emerging market economies as a whole (Bandura and Ramanujam, 2019 ${ }_{[3]}$ ). Guarantees have been successfully used to deepen local capital markets, for example by facilitating localcurrency bond issuance to allow public and corporate sector actors to raise funds in local currency 
(GuarantCo, 2019[38]) (Sida, 2015[39] $)($ IFC, 2014[40] $)$ as well as supporting municipal bonds (USAID, $\left.2014_{[41]}\right)$. This, in turn, allows for improved access to domestic financing. In development finance, guarantee schemes for local bond issuers are already present, yet there is scope for wider use.

Guaranteeing local currency bonds may also promote better targeting of underserved sectors that traditionally encounter problems obtaining financing in hard currency. This is especially troubling for projects in which revenue streams are denominated in local currency and which may not bring revenues in the short-term. A successful example is GuarantCo (Box 1.7) which was established to provide credit guarantees that help access to financing for infrastructure projects in developing markets. Another example is the EFSD African Local Currency Bond Guarantee Programme (ALCBGP), primarily directed at subSaharan Africa. EFSD guarantees will enable local bond issuers to provide financial services or direct investments for a range of sectors, including agriculture, healthcare and education (European Commission, $\left.2019_{[23]}\right)$. However, it is worth emphasising that guarantees are not a panacea for local financial market development, as there are several preconditions that have to be met, such as an appropriate local savings and investors environment, sound macroeconomic policies, and proper institutional and legal frameworks (Bandura and Ramanujam, 2019 $9_{[3]}$ ).

\section{Box 3.1. IFC's Partial Credit Guarantee (PCG) for Bonds}

IFC's Partial Credit Guarantee (PCG) for Bonds is designed with an emphasis on providing long-term local-currency solutions in developing markets. For example, in 2014, IFC supported the issuance of bonds by a leading Indonesian property company by providing a $20 \%$ guarantee for a 500 billion Indonesian rupiah issuance (approximately USD 44 million). These bonds, receiving a partial credit guarantee from IFC, were the first of this kind in Indonesia. This success was due to the guarantee enhancing the bonds' national credit rating. The issuance was oversubscribed and sold to a variety of local investors, including pension funds, banks, and insurers. Proceeds were used to support the construction of low-rise houses and relevant facilities in developments across Indonesia.

Source: (IFC, 2014[40]), IFC Provides Innovative Credit Guarantee to Strengthen Indonesian Capital Markets, Green Finance, https://ifcext.ifc.org/ifcext/Pressroom//FCPressRoom.nsf/0/6E81AADC01910C1785257CAF001FCF32

\section{Backstopping financing for large-scale infrastructure projects}

Infrastructure development is a key driver for progress across many developing countries yet it is largely constrained by the availability of long-term debt finance (Pereira dos Santos, 2018[42]). In infrastructure project finance, credit risk tends to be relatively high at project inception and construction and then diminish over the life of the project due to, among others, possible delays in construction, cancellation of permits, and difficulties in land acquisition. Financing large-scale infrastructure projects requires lenders not only to commit to long maturities, but projects usually undergo different phases characterised by different risks and cash flow patterns, and they are particularly exposed to the risk of political changes. Guarantees are shown to be a particularly relevant risk-mitigation instrument for infrastructure investments, as they can be tailored to specific project risks, such as construction period risk or the non-payment by a sovereign guarantor of the project (Pereira dos Santos, 2018[42]). 


\section{Mitigating political risks}

High levels of political risk are often the primary reason for the lack of private investment in the LDCs and fragile states (MIGA, 2014[43]). Political risk insurance/guarantees are an effective solution in such cases as they allow investors and lenders to transfer political risks to a third party that might be better able to assess and bear such risks (WEF, 2016[44]). However, currently there is a lack of provision and purchasing of political risk insurance/guarantees in fragile states, due to both demand and supply reasons. On the supply side, it is linked with pricing of such products on the market, as well as their limited availability (while the private market for political risk insurance is growing, its provision in fragile states remains restricted). As noted by MIGA, such products are also concentrated in a limited number of resource-rich countries, mirroring FDI flows (MIGA, 2011 ${ }_{[45]}$ ) and are underwritten by a small number of private insurers. On the demand side, political risk guarantees are mostly used by foreign investors, given that insurance companies have a requirement to insure cross-border investments (Mayer, 2017[46]). Such limitations could be remedied by enhanced co-operation between donors/donor-supported providers and private entities, for instance by pursuing coinsurance and reinsurance.

\section{Using guarantees as triggers for market change}

The economic environment of emerging economies can be substantially volatile, uncertain and complex. Yet, in such contexts, guarantees can generate significant impact. As shown by the GuarantCo-supported Infrastructure Credit Guarantee Company (InfraCredit) in Nigeria, guarantees can be used as initial triggers of market change. By supporting infrastructure bond issuance denominated in local currency, InfraCredit succeeded in crowding-in local pension funds. Before this, only relatively few Nigerian infrastructure securities had strong enough credit ratings to be investable by pension funds. Demonstration effects are necessary in the LDCs, where perceptions of risks may not be aligned with the actual risks in these markets, as is often the case. Particularly first-loss guarantees can be used to create a demonstration effect to develop a market in fragile context (Bandura and Ramanujam, 2019[3]). Moreover, using guarantees to enable access to finance for SMEs in underserved market segments may also generate positive externalities simply by encouraging banks and non-bank financial institutions to enter into the SME market.

\section{Box 3.2. InfraCredit - Infrastructure Credit Guarantee Company}

An example of a local champion driving change in local market is InfraCredit - Infrastructure Credit Guarantee Company, operating in Nigeria. It was established by GuarantCo and the Nigeria Sovereign Investment Authority to provide local currency guarantees and enhance the credit quality of debt instruments issued to finance infrastructure assets in Nigeria. InfraCredit filled a market gap in Nigeria where underserved clients had trouble accessing capital. Since investors tend to associate infrastructure projects with high risk (although the real risk is usually lower than the perceived), the risk dissipation factor of guarantees plays an important role in making the investments commercially successful. By supporting infrastructure bond issuance denominated in local currency, InfraCredit succeeded in crowding-in local pension funds. To build up trust and diminish risk exposure, InfraCredit ensures that all guaranteed projects comply not only with national regulations, but with best practices from the global markets (such as enhanced due diligence, KYC procedures, and multiple layers of compliance). Once a critical mass of local capital and investors is achieved, it is easier to attract new institutions. Donors could help replicate this model of specialised guarantee entities across developing countries, as they are strongly anchored in their respective markets. 


\section{Collaboration among guarantee providers for reaching underserved markets}

Guarantees allow organisations with different priorities and capacities to invest alongside each other while achieving their respective objectives and drawing on the strengths of different participants. Moreover, collaboration between providers can create significant additionality when one provider cannot issue a guarantee in a specific sector or country (due to having already fulfilled its mandate in that area) but is able to do so when sharing the issuance with another provider. Additionally, as shown by the collaboration between USAID and Sida to deliver the Health Guarantee to Centenary Rural Development Bank in Uganda (2012-2019), institutions that start issuing guarantees can draw from the experiences of more established providers (for Sweden it was one of the first guarantees that Sida engaged in) (Sida, 2018[48]). Collaboration should not be limited to the provision of a standard set of guarantee products, but also consist of identifying ways to jointly solve the biggest obstacles that are obstructing the more widespread usage of these instruments, especially in the LDCs. Yet, it is important to note that scaling up collaborative approaches for guarantees may be hampered by an inadequate level of standardisation among the different guarantee providers and insurers. Developing a common set of principles or standards could assist donor governments in establishing, operating, and evaluating guarantees that serve development purposes. Moreover, collaboration among guarantee providers, especially where it allows for combining guarantees with technical assistance, may overcome some of the underlying obstacles that deter private investments from materialising, specifically in the least developed and fragile states. In this sense, collaboration between guarantee providers may allow for calibrating more effective support packages that could comprehensively address both risk and return constraints, as well as allow for structuring operations that generate more financial and development additionality. 


\section{Box 3.3. Co-Guarantee Platform}

A recent example of collaboration among guarantee and insurance providers in Africa is the CoGuarantee Platform (CGP), where a group of participants have come together to find solutions to transactions. The CGP was created in 2018 by the African Development Bank (AfDB), GuarantCo, the Islamic Corporation for the Insurance of Investment \& Export Credit (ICIEC), the African Trade Insurance Agency (ATI) and the African Export-Import Bank. The CGP combines institutions with different risk mitigation products to work on specific projects in Africa. It is an African-based solution to scaling up the risk mitigation required to mobilise greater finance and investment across the continent for infrastructure, trade, and key economic sectors. The platform does not pool financial resources, but serves as a marketplace for guarantees. It offers the opportunity to exchange know-how, capacity, credit rating and experience to provide solutions to businesses in need of a guarantee. There are two ways in which the CGP can help a client:

- Contacting the CGP directly enables the CGP members to discuss the best way to put together a proposal that satisfies the client's needs through a centralised discussion that allows for the comparison of options across members' capacities.

- When a guarantee provider which is member of the platform cannot provide a solution to a client by itself, it contacts the community of CGP members to search for the additional resources (be it financial, sectorial or know-how) needed to provide the client with a solution. For instance, only certain members of the CGP can issue guarantees in local currency. This allows a member which cannot issue local currency guarantees itself to partner with a member that can provide such guarantees.

Source: (Private Infrastructure Development Group (PIDG), n.d.[15]), https://guarantco.com/2018/11/02/african-development-bankinternational-financial-institutions-launch-first-ever-co-guarantee-platform/

\section{Supporting specialised guarantee providers}

Supporting specialised guarantee providers with targeted sectoral and/or geographic coverage is one way of reaching underserved sectors in developing countries. Bilateral donors, DFls and MDBs have already participated in setting up specialised guarantee providers, such as GuarantCo, FrontClear, or AGF. By pooling resources and offering targeted support, such institutions address the challenges of fragmentation and the inefficiencies of development finance in particular geographies (OECD, 2016[49]). Additionally, specialised guarantee providers, who do not follow rules intended for banks when accounting for guarantees, have the ability to leverage their balance sheet without borrowing, especially when the guarantees they offer are unfunded (Bandura and Ramanujam, 2019[3]). Such schemes may be capitalised by the private sector, while multilateral and bilateral funding could help for leverage. Such specialised entities may deploy tailored guarantees that provide a commercially attractive proposition in local markets. As they are smaller and less complex than MDBs, they may be able to respond more quickly to market needs. In terms of using guarantees, customisation by understanding local context circumstances is crucial in order to achieve development impact. As each developing country faces specific credit market development barriers, a standardised approach to overcoming these barriers across countries will not be effective. Overcoming unique and local barriers to finance requires the decentralisation of risk mitigation and the development of specialised solutions and instruments. 


\section{Box 3.4. The African Guarantee Fund (AGF)}

Background: The African Guarantee Fund for Small and Medium-Sized Enterprises Ltd (AGF) was created in 2011 by the African Development Bank (AfDB), the Danish Ministry of Foreign Affairs (through DANIDA) and the Spanish Ministry of Foreign Affairs and Co-operation (through AECID) with USD 50 million initial capital. The Founding Shareholders were later joined by the French Development Agency (AFD) in 2015, the Nordic Development Fund (NDF) in 2016, the German Development Bank (KfW), and the Danish Investment Fund for Developing Countries (IFU) in 2018. The capital of the company amounted to USD 180 million as of 31 December 2019. Since it officially started operations in June 2012, the AGF has issued USD 1.1 billion of guarantees to 161 Partner Financial Institutions (PFIs) in 40 countries in Africa.

Business Model: AGF aims to boost access to finance through:

(i) the provision of financial guarantees to PFIs to support their lending to SMEs, women, youth and to the climate adaption and mitigation value chains, thereby enabling the PFIs, which are primarily banks and non-bank financial institutions, to increase their portfolio of loans to the target end beneficiaries across Africa;

(ii) the provision of capacity building support for both the PFIs to enhance their financing capability and to the beneficiary enterprises to improve their business management skills, via a capacity development facility.

AGF offers market oriented credit guarantee products that comprise:

- Loan Individual Guarantees (LIG) to guarantee a single loan made by a financial institution to a single borrower whose identity is known.

- Loan Portfolio Guarantees (LPG) to guarantee a portfolio of loans made by a financial institution to a targeted borrower segment (Qualifying Borrowers) for which the parameters have been defined but the individual borrowers are not known at the time of the guarantee agreement.

- Bank Fund Raising Guarantees (BFRG) to guarantee bonds issued by a PFI to investors for the purpose of raising long-term resources to finance SMEs.

- Equity Guarantees (EG) to guarantee equity investments made by a private equity fund or venture capital fund in an SME.

- Green Guarantee Facility (GGF), which can be in form of LIG, LPG, BFRG or EG. The goal of this product is to enhance access to finance for green growth-oriented SMEs and build banks' knowledge and capacity to scale up lending to the green economy.

The price of each guarantee is calculated using an internally-developed risk-based pricing model. The AGF's competitive advantages are its efficient processing of guarantee requests and payment of claims, combined with its ability to design bespoke facilities in order to address the ever-changing needs of the financial institutions.

Development Results: In order to capture the impact achieved by the organisation's guarantees in a timely and adequate fashion, the AGF designed and implemented M\&E processes embedded in all stages of a guarantee life cycle (i.e. from origination to guarantee expiration). Internally developed systems and tools support the processes. The table below summarises the impact of the AGF as of 31 December 2019: 


\begin{tabular}{|l|c|c|}
\hline Indicators & & Amount \\
\hline Greenhouse Gas Avoided & Co2t & 3.8 million \\
\hline $\begin{array}{l}\text { Number of households with access to clean } \\
\text { energy }\end{array}$ & $\#$ & 19.9 million \\
\hline Cleaner energy capacity installed & $\mathrm{KW}$ & 57,005 \\
\hline Financing disbursed to SMEs & USD & 1.7 billion \\
\hline Number of SMEs benefiting from AGF facilities & $\#$ & 20,800 \\
\hline$\bullet \quad$ Of which Youth Owned -SMEs & $\%$ & $60 \%$ \\
\hline$\bullet \quad$ Of which Women Owned-SMES & $\%$ & $30 \%$ \\
\hline Number of additional jobs created by SME & $\#$ & 129,130 \\
\hline Number of Countries & $\#$ & 40 \\
\hline Number of PFIs & $\#$ & 161 \\
\hline $\begin{array}{l}\text { Number of PFIs and SMEs Trained in Climate } \\
\text { Finance }\end{array}$ & $\#$ & 101 PFIs \\
\hline $\begin{array}{l}\text { Guarantees Issued to Partner Financial } \\
\text { Institutions (PFIs) }\end{array}$ & USD & 1.1 billion \\
\hline Value of capacity development initiatives funded & USD & 3.8 million \\
\hline
\end{tabular}

Source: (African Guarantee Fund, n.d. $[14])$, www.africanguaranteefund.com, and interview. 


\section{Why guarantees may be particularly relevant in the coronavirus (COVID-19) context}

\section{Coronavirus (COVID-19) and guarantees}

Guarantees are a key part of the economic recovery in response to COVID-19 crisis in both developed and developing countries, (BIS, 2020[50] (Calice, 2020[51]). At times of such systemic stress and constrained budget resources, guarantees can be used to diversify donors' funding options and create greater stability for financial flows to developing countries. Unfunded guarantees are a particularly relevant tool under the current circumstances as they allow guarantors to leverage their capital more efficiently. Moreover, as most bilateral DAC aid agencies can benefit from sovereign credit rating, they can take on more risk when issuing guarantees. Although default rates are expected to be higher than usual during the ongoing COVID-19 crisis, and although there is no clear blueprint for the design of guarantees during crises, guarantees (both funded and unfunded schemes) have already featured as part of donors' comprehensive policy response in developing countries. While it may take time to design and set up new guarantee schemes, existing schemes can be scaled relatively easily and can be quickly re-oriented to meet the new circumstances caused by the COVID-19 crisis. For instance, during the first months of the pandemic the European Commission increased its available funding through the EFSD Guarantee and refocused the programme specifically to tackle the COVID-19 crisis (European Commission, 2020[52]). The re-focused EFSD Guarantee prioritises small businesses and healthcare. MIGA also quickly launched a USD 6.5 billion fast-track guarantee facility to help investors and lenders tackle the crisis and, since then, the facility has provided USD 2.1 billion for projects. 


\section{Box 4.1. MIGA's COVID-19 response}

The MIGA fast-track guarantee facility targets low-income, fragile and conflict-affected countries. By September 2020 these settings constituted nearly half of all projects supported by the facility, which is structured along the following three lines:

1) Support for the Urgent Health Response. MIGA provides guarantees to credit-enhance governments to secure financing provided by foreign commercial lenders or credit extended by medical suppliers for procuring urgent medical supplies and services. MIGA's financing could be additional to World Bank and IMF financing in order to serve unmet needs or help free up these resources for the most vulnerable countries.

2) Countering Adverse Economic Impacts during the COVID-19 Crisis. MIGA provides guarantees to credit-enhance commercial borrowings by sovereign, sub-sovereign and SOE clients for urgently needed short-term funding and working capital support to SMEs, corporates and individuals during the COVID-19 crisis.

3) Trade Finance. MIGA provides guarantees to enable IFC to help sustain short-term trade activities in IDA/Fragile and Conflict-Affected States (FCS) and LMICs affected by severe economic and trade disruptions linked to the COVID-19 crisis.

Source: (World Bank, 2020[53]), Covid-19 Approach Paper, http://documents1.worldbank.org/curated/en/136631594937150795/pdf/WorldBank-Group-COVID-19-Crisis-Response-Approach-Paper-Saving-Lives-Scaling-up-Impact-and-Getting-Back-on-Track.pdf

There are two key advantages to using guarantee schemes in response to the COVID-19 crisis. First, for those institutions already using guarantees, the deployment of this instrument can be rapid and easily scaled up. In particular, balance sheet and portfolio guarantees can unlock large amounts of financing in specific sectors or areas that have been hit hardest by the pandemic. Second, as guarantees do not require an immediate outflow of funds, they are an attractive blended finance tool. This is particularly the case given the fact that decreasing economic growth in developed countries will result in a reduction in the absolute amount of ODA available. When time is of essence, guarantees are an appropriate blended finance solution, as they also allow for a portfolio approach in addition to a loan-by-loan approach.

\section{Scaling up short-term responses to coronavirus (COVID-19) by expanding small and medium-sized enterprise finance and supporting viable businesses}

COVID-19 and its accompanying lockdowns have taken their toll on SMEs, who have suffered from a sharp fall in operating earnings. In response to the crisis, almost two-thirds of EBRD countries have either expanded an existing guarantee scheme or implemented a new one (Cracan, Kresic and Milatovic, $\left.2020_{[54]}\right)$. These schemes specifically target SMEs that urgently need liquidity in order to re-start their activity after the lockdown measures are eased. Guaranteeing lending or balance sheets of normally economically viable businesses can act as a key catalyst to stimulate a return to normal economic activity once the risks posed by the pandemic have been successfully mitigated.

Certain middle-income countries (MICs), such as Turkey, Georgia, and Jordan, were able to quickly scale up existing government-supported guarantee schemes or start new ones (Cracan, Kresic and Milatovic, $2020_{[54]}$ ), but government-backed guarantee schemes in the LDCs have not been prevalent. It is therefore key for DFIs, MDBs and specialised providers to fill the gap and expand their guarantee operations to markets where the state cannot provide them directly. Many development finance providers are already taking action to support SMEs across the world, which are facing major cash flow problems. For instance, 
the European Commission or the AGF, apart from guaranteeing new loans, are currently focusing on guaranteeing existing portfolios of loans and helping SMEs in developing countries to stay afloat. In instances of immediate liquidity problems facing SMEs in LDCs, local currency credit enhancement, such as partial credit guarantees, may help to extend the tenor of available local currency financing, e.g. by covering later maturity payments or a certain amount of debt service payments. This also has the additional benefit of helping to develop and strengthen local financial markets. However, there are also limits to the operational capacity of institutions issuing guarantees, which will be tested by the high number of applications such institutions are likely to receive.

\section{Box 4.2. Boosting small and medium-sized enterprise finance during COVID-19}

Most economies rely on SMEs for the majority of their jobs, and the SMEs have been among the worst hit by the COVID-19 pandemic. In response, many international institutions have boosted their support for the SME sector. In April 2020, the EU launched the "Team Europe" package in order to support partner countries' efforts in tackling the COVID-19 pandemic. As part of the package, the EC and FMO topped up the NASIRA Risk Sharing Facility with an extra EUR 25 million (bringing the total value to EUR 100 million) and refocused its scope to also include entrepreneurs negatively impacted by COVID19. Previously, NASIRA focused primarily on young, female, migrant entrepreneurs. The aim of the new measures is to help more SMEs stay afloat and mitigate the socio-economic impact of the pandemic. Similarly, the EIB stepped up its support to the SME Access to Finance Initiative. This initiative is designed to facilitate access to capital for underserved areas such as businesses run by women or by youth. The COVID-19 response also expanded the scope to allow SMEs affected by the pandemic to access enhanced partial portfolio guarantees, which provide first-loss coverage of up to $80 \%$ on loans.

Source: (EIB, 2020[55]), SME Access to Finance Initiative: European Union to boost support for small and mid-sized businesses in neighbouring countries, https://www.eib.org/en/press/all/2020-015-sme-access-to-finance-initiative-european-union-to-boost-support-forsmall-and-mid-sized-businesses-in-neighbouring-countries

(European Commission, 2020[56]), EU and FMO scale up NASIRA guarantee in fight against the COVID-19 pandemic, https://ec.europa.eu/commission/news/eu-and-fmo-scale-nasira-guarantee-fight-against-covid-19-pandemic-2020-apr21 en\#: : :text=Search-

EU\%20and\%20FMO $\% 20$ scale $\% 20$ up $\% 20$ NASIRA $\% 20$ guarantee $\% 20$ in $\% 20$ fight $\% 20$ against,by $\% 20$ the $\% 20$ COVID $\% 2$ D $19 \% 20$ pandemic

\section{The role of guarantees in supporting health systems during the crisis}

In many developing countries the COVID-19 crisis has exacerbated challenges already present in domestic health systems which are often short of resources (OECD, 2020[57]). In the current context, these resources are primarily directed to measures to contain the virus as well as to maintain basic and critical health services. Yet, the crisis also threatens to derail progress achieved so far in the health sector, for instance through supply chain disruptions to the provision of critical medicines and medical supplies. Before the COVID-19 crisis, guarantees had already been used in the health sector but not deployed at scale. ${ }^{12}$ This is due to a number of reasons, such as the fact that health sector profit margins are often low and incompatible with interest rates imposed by financial institutions. There are also high costs and failure rates for new medicines, and uncertain markets with rapidly changing health threats (Convergence, 2020[58]). Blended finance has traditionally been more prevalent in commercially-oriented sectors and the privatisation of the health sector has been met with criticism (Lethbridge, 2017[59]). As the poorest will most often rely on public health service, private health clinics are not likely to directly reach poor populations. There is an ongoing debate on precisely how the private sector ought to contribute to the health sector, given the varying functions it can perform ${ }^{13}$ (Stallworthy et al., 2014[60]) (Wolf and Toebes, 2016[61]). 
Yet, in the current context, due to constrained public resources in the wake of the COVID-19 crisis, there is a case for the use of guarantees to address the most critical gaps in the provision of health services. For example, guarantees have been used by MIGA to credit-enhance governments to secure financing for procuring urgent medical supplies and services (Box 4.1). Further to this, the European Commission has refocused its EFSD Guarantee to put more emphasis on mobilising private resources and deliver critical diagnostic services for low-income populations in LDCs. Team Europe (the European Commission and the European Investment Bank) has also contributed EUR 400 million to the COVAX Facility in the form of guarantees. This Facility will serve as a procurement platform for COVID-19 vaccines. It includes a mechanism - known as the COVAX Advance Market Commitment - through which low and middle-income countries can get access to COVID-19 vaccines ${ }^{14}$.

\section{Box 4.3. European Health Guarantee Platform for Africa}

A recent example of the use of guarantees in the health sector is the European Health Guarantee Platform for Africa. It is backed by the EFSD Guarantee, with a budget of up to EUR 80 million and up to EUR 12.5 million for technical assistance. The Platform is being developed by the EIB as the lead financial institution, in close co-operation with the Bill \& Melinda Gates Foundation. Its objective is to strengthen diagnostic services for low-income populations in northern and sub-Saharan Africa. The Platform guarantees payment for services, as in low-income countries private providers for diagnostic services face the risks that governments may not meet theirs contractual obligations. The guarantee aims to facilitate payments for quality diagnostic services, especially for diseases such as tuberculosis, HIV, and malaria, and encourage further private investment into healthcare in the region.

Source: (European Commission, 2020[62]), European Health Guarantee Platform for Africa, https://ec.europa.eu/eu-external-investmentplan/content/european-health-guarantee-platform-africa_en

In the past, donors have tested the applicability of guarantee schemes throughout various segments of the health sector e.g. to encourage local lending to private health enterprises or provide credit enhancement to health infrastructure. For instance, the USAID/DCA partnered with Sida to provide a seven-year, USD 3 million loan portfolio guarantee to the Centenary Bank to increase access to credit for the Ugandan health sector and encourage local lending to private health enterprises (Sida, 2018[48]). In Turkey, the EBRD, together with MIGA, provided a joint credit enhancement scheme to enable the issuance of the first greenfield infrastructure project bond in Turkey to finance the Elazig Integrated Health Campus. This innovative credit-enhancement scheme increased the buy-in from other investors and enabled Moody's to assign a Baa2 rating, two notches above the sovereign rating of Turkey (OECD, 2018 $\left.{ }_{[18]}\right)$. One of the principal aims of the project was to bring a demonstration effect of new ways of financing, procuring and operating hospital infrastructure. Another example of using guarantees in the health sector is deploying volume guarantees to de-risk the production of medical supplies, i.e. investors commit to procure larger orders from medical suppliers, enabling them to forecast production and capture efficiencies from economies of scale (BSR, 2017[63]).

Given their utility as a de-risking tool, and specifically in the context of constrained public budgets due to the current crisis, guarantees have a role to play in supporting health systems. However, there is scope to further investigate when and under what conditions guarantees are the most effective and appropriate solution to address COVID-19 related challenges in the health sector. 


\section{What could be done to incentivise and improve the use of guarantees?}

This paper has presented an overview of the key advantages of development guarantees. It has outlined the contexts and ways in which their use can be of particular value to addressing the economic consequences of the COVID-19 pandemic and driving more private capital towards underserved markets. While evidence indicates the use of guarantees is gaining traction across the world, there is still considerable room for improvement. This section presents a number of initial ideas for what could be done to strengthen incentives for donors to scale up and improve the use of guarantees.

\section{Improving incentive structures for donors in terms of the ODA-eligibility of guarantees}

The process of modernising ODA and the DAC statistical framework was initiated several years ago and has involved specific discussions on private sector instruments (PSI). Specifically, how to recognise and hence count in ODA the scale of donor effort involved in deploying these instruments to incentivise their use. However, the process of reaching agreement on the implementation details has yet to be concluded. As a consequence, the provision of guarantees is not incentivised through ODA-eligibility mechanisms. ODA-eligibility is an important factor for many donors in their choice of development finance instrument. Further discussions on how to provide better incentive structure for donors regarding the use of guarantees in their bilateral programmes will be needed to widen the use of the instrument.

\section{Box 5.1. Lack of agreement on the ODA-eligibility of individual guarantees}

The 2016 high-level meeting (HLM) agreed on a set of principles designed to ensure that the DAC statistical system would reflect the effort of the official sector in providing PSIs in a credible and transparent way while offering the right incentives and removing disincentives in the use of these instruments (HLM Communique, 2016). The principles established that:

- Efforts of the official sector in providing PSI would be counted as ODA, while the financial flows themselves would be tracked in the broader measure of total official support for sustainable development (TOSSD). The efforts could be measured either at the point of the transfer of funds to a vehicle providing PSI to developing countries (the institutional approach), or for each PSI transaction between the vehicle and the private enterprise or institution in the partner country (the instrument-specific approach);

- The measurement of donor effort would be based, when possible, on the grant equivalent method. Under the instrument-specific approach, the measurement of donor effort would be based on the system of risk-adjusted grant equivalents, and under the institutional approach, donor effort would be measured at the point of the placement of funds in the DFI or other vehicle 
in the donor country. Under both approaches, any dividends or profits on PSI paid back to the government would count as negative ODA.

The method for calculating ODA was established for different financial instruments (grants, reimbursable grants, loans, equity investments (in a DFI and by a DFI), and guarantees. It was agreed that guarantees would be counted on a grant equivalent basis, applying differentiated discount rates and, when appropriate, an additional risk premium for the private sector. As guarantees are non-funded instruments, the discount rates would only take into account operating costs and risk adjustment factors (not the funding cost).

The HLM 2016 meeting also pledged to develop proposals for the implementation details of the principles including thresholds, assessment criteria, the definition of additionality, the definition of a lock-in period, risk premium, discount rates and reporting requirements and data disclosure. In relation to the method for calculating ODA for guarantees, it was agreed that the DAC Secretariat would work with DFIs to establish the relevant discount rates and the risk premia for the private sector, as well as formalise the grant equivalent methodology to be applied on public guarantees, and on guarantees other than credit guarantees. At the DAC HLM in October 2017, members reaffirmed the principles agreed at the $2016 \mathrm{HLM}$. At the same time, pending agreement on the implementation details of all the PSI principles, the HLM reaffirmed that donor efforts to support PSIs could be measured either using the institutional approach or the instrument-specific approach. The meeting pledged to finalise the implementation rules of the PSI agreement by collecting evidence on the impact of PSI, and revise rules where appropriate. From October 2017 to December 2018, discussions continued and attempts were made to reach an agreement on the detailed implementation rules for the PSIs. However, no agreement could be reached, primarily due to a disagreement over the discount rates to be used in calculating the grant-equivalent of loans to private sector companies (PSI loans), equity investments, mezzanine finance and guarantees.

Pending a final agreement on the PSI implementation rules, in December 2018 members provisionally agreed on the reporting methods for PSIs to be applied in their reporting on 2018 ODA. The reporting methods were elaborated and integrated as Addendum 3 in the Statistical Reporting Directives. The Addendum 3 specifies that the reporting methods are provisional and remain in place until members agree on the implementation details of the PSI principles. It further reaffirms members' commitment to review and revise these provisional arrangements, should the PSI implementation rules have not been agreed upon by 31 December 2020.

Source: (OECD, 2021[22]), Converged Statistical Reporting Directives for the Creditor Reporting System (CRS) and the Annual DAC Questionnaire: Reporting methods for private sector instruments (Annex 23),

https://one.oecd.org/document/DCD/DAC/STAT(2020)44/ADD3/REV2/en/pdf

\section{Co-ordinating guarantees and insurance to deliver on development}

The OECD Creditor Reporting System does not make a distinction between guarantees and insurance. Their significant role in mobilising private finance despite the small amounts of development finance allocated underlines the demand for such products by the private sector. Overall, the key benefit of guarantees and insurance products is that they can be tailored to specific risks, such as construction period risk or the risk of breach on the concession needed for the project or non-payment by a project's sovereign guarantor. These solutions can have specific developmental or social impact as they facilitate the mobilisation of large amounts of financing by taking only a specific portion of the total risk involved. 


\section{Box 5.2. Insurance versus guarantees}

There are certain differences between guarantees and insurance. Guarantees are often financial in nature and result in payment by a guarantor in the event of non-payment by a guaranteed entity to a third party. That is, if Party A does not meet its obligations to Party B, those obligations can be covered and paid for by Party $C$ or an insurer, bank or any other entity serving as a guarantor. Meanwhile, insurance policies can serve the same function, but often include additional conditions that need to occur before payment takes place. These conditions can often take the form of particular risks, situations, types of damage and contingent damages and losses. In this respect, insurance policies can be more flexible in terms of variations of causes that can trigger payment to the insured. They can range from natural catastrophe events like fires, to more complicated events, such as political violence and expropriation. Insurance products are often tailored to the needs of an insured entity rather than the standardised structure for a guarantee and are not necessarily related to an obligation to fulfil a service or payment.

According to a report by Milken Institute and the OECD, private sector actors favour guarantees over insurance products based on concerns relating to proving the causation between the insured risk and the payment default with insurance (Lee, Betru and Horrocks, 2018[4] $)$. This issue can be resolved by insurance products that cover both commercial and political risk (comprehensive insurance), and products which insure against failure to pay (e.g. sovereign non-honouring covering for payment obligations) can address causation concerns and work just as effectively as a guarantee. Recognition of insurance as a separate instrument could increase the likelihood that greater innovation and engagement of the private sector could occur.

In the wake of the COVID-19 crisis, DFls' balance sheets are unlikely to significantly increase. Yet, guarantees and insurance could be effective tools not only at the mobilisation level but also at the balance sheet level. For instance, Sida's unfunded guarantees approach, and MIGA's reinsurance, provide further space for investments on their balance sheet. In the case of MIGA, the risk is effectively priced allowing exposure to be sold to reinsurers. The COVID-19 crisis is likely to increase the need for such approaches, allowing donors to do more with less through balance sheet optimisation. Therefore, development actors could consider further engaging and exploring the role that insurance products and services can play in addressing the SDGs.

Platforms to share solutions, particularly on insurance products, could also help donors and actors come together in terms of finding appropriate mechanisms. In order to make the most of insurance sector knowledge in assessing risks, collaboration between private insurers and donors is essential. In this context, there is a need to address the risk management gap. The AON, OECD and IDF report highlighted the need for a coherent approach to the whole risk challenge at sovereign and sub-sovereign levels, and across government departments, development agencies and the private sector (AON, 2017 ${ }_{[64]}$ ). The report pointed to the fact that - with a few notable exceptions - this is not common practice; due to political and other pressures, governments tend to react to crises, hazard by hazard, as opposed to adopting forwardlooking risk management plans.

However, only a risk management plan that emphasises resilience over reaction can accelerate progress towards protection and growth at scale. Such a plan must include cross-sector investment in risk prevention and create the conditions for development of insurance and risk finance markets. Innovative solutions and ideas to help bring blended finance and insurance together are being developed. For example, a Lloyd's Innovation Lab study suggested a number of blended instruments (using financing instruments and insurance together) for a connected approach (AON, 2017[64]). One example is loan payments for investment in adaptation being offset by attractive insurance premium reductions based on the reduced 
risk exposure. As highlighted, insurance and guarantees need to work alongside each other. Insurance can help leverage the financial contribution made by investors to enable better efficacy out of each invested dollar. This in turn protects the return of the guarantees targeted investment.

\section{Other best practices to improve the use of guarantees}

\section{Promoting partial guarantees and market rates to ensure accountability}

Guarantees, as other blended finance instruments, should ensure the alignment of incentives among different parties in the transaction. Guarantees covering $100 \%$ of a transaction could lead to moral hazard on the side of the guaranteed party, i.e. a misalignment of incentives given the guaranteed party bears no risk at all. To mitigate this risk, guarantors usually only offer partial guarantees. Providing full coverage of an investment can also shift investors away from other investment opportunities and distort the market. Thus, guarantees should be designed such that investors' and borrowers' incentives are aligned to the highest possible extent in order to reduce the possibility of creating a moral hazard, minimise market distortions at the local level and avoid draining liquidity from other non-risk-free projects. While in some cases donor-backed guarantee providers subsidise part of the guarantee fee, this should be the exception rather than the norm in order to ensure that close-to-market rates are predominant and that donors do not crowd-out private financing already available in a given market. A higher share of concessionality, such as in the form of subsidising fees (on either a project or portfolio level) is typically required to catalyse private investments in the LDCs, especially where market-based instruments do not exist.

\section{Deploying guarantees only for uses where commercial financing is not currently available}

In markets serviced by a number of guarantee providers, especially private ones, it is crucial that donorbacked guarantees are additional to existing financing and do not crowd-out private guarantors. While designing guarantee schemes, donors should pay particular attention to ensuring their financial sustainability. Guarantees ought to be phased out once the investee generates sufficient cash flows and markets are developed enough to attract commercial investors. Guarantees should ideally be time-bound, with credible expectations that they will be phased out over time. One solution for minimising concessionality over the life cycle of a guarantee is providing adjustable pricing. Another, where guarantee recipients' objectives are longer-term (e.g., testing a new market), is to limit coverage level over time (GIIN, 2017[24]). However, it should be noted that different institutions (aid agencies, DFIs, MDBs) have varying capacity in risk assessment and management, and adjusting financial risk-return models of guarantees over the instrument's lifecycle may be a burdensome exercise.

\section{Promoting competition}

In order to scale up the market of guarantees and ensure they are used effectively, competition should be promoted among banks/investors that obtain guarantees. For instance, issuing guarantees for multiple banks in the same area instead of just for one could introduce competition in the market and incentivise banks to develop the instrument by offering different structures in order to attract as many clients as possible, such as by varying coverage, fees, and maturity. This can further scale-up the market of guarantees and promote the best use of the instrument.

\section{Standardisation and increasing co-operation between guarantee providers}

In order to scale up the market for guarantees and significantly increase their use, both the standardisation of the product and an increased collaboration between guarantee providers is essential. One option for 
consideration is developing more programme-level guarantee schemes which would allow for the application of standard terms across larger sets of investments or loans (GIIN, 2017[24]). This could entail, for instance, creating standard criteria for specific sectors in given geographies. In order to increase the efficiency of structuring and negotiating guarantees, whilst enhancing collaboration between guarantee providers, creating standard contract templates to be used as "entry points" for negotiations and accepted by a number of guarantors could also be a viable option.

\section{Funded vs. unfunded guarantees}

With no immediate outflow of cash necessary to finance projects, unfunded guarantees are less capital intensive than funded guarantees, and can therefore mobilise capital more effectively. However, both types of guarantees have a component of exposure because both cover default risk. In principle, the underlying risk in both funded and unfunded schemes should be calculated and covered through the premium and (if deemed necessary) a subsidy element, as the scheme would otherwise suffer a loss. In markets where default risks are assessed to be high, premiums would also need to be high in order to cover the expected defaults. If premiums have a concessional element to ensure the partner institution can afford the guarantee, the subsidy amount should also be reserved to cover expected losses (such as in Sida's model). In markets where default rates are assessed to be low, premiums should correspondingly be lower and, in such markets, the need for concessional funding may also be lower (in this case, the additionality of using guarantees may also be relatively limited). While unfunded schemes mobilise capital more efficiently than funded schemes, they also require broader diversification of the guarantee portfolio in order to reduce total exposure. If the guarantee portfolio is limited, the impact of a total default of some of the guarantees is higher and, in such situations, a funded (or partially funded) guarantee scheme may be preferable. 


\section{References}

Aceli Africa (2020), Bridging the Financing Gap: Unlocking the Impact Potential of Agricultural

SMEs in Africa, https://aceliafrica.org/bridging-the-financing-gap-unlocking-the-impact-

potential-of-agricultural-smes-in-africa/.

African Guarantee Fund (n.d.), africanguaranteefund.com.

AON (2017), Overcoming barriers to close the protection gap,

https://aoncomauthoring.blob.core.windows.net/aoncom2017media/aon.com/media/reinsuranc e/aon-overcoming-barriers-to-close-the-protectiongap-report.pdf.

Bandura, R. and S. Ramanujam (2019), Innovations in Guarantees for Development, Center for Strategic \& International Studies, https://csis-website-prod.s3.amazonaws.com/s3fspublic/publication/191016 BanduraRamanujam Innovations WEB.pdf.

Barder, O. and T. Talbot (2015), Guarantees, Subsidies, or Paying for Success? Choosing the Right Instrument to Catalyze Private Investment in Developing Countries, Center for Global Development Working Paper, https://www.cgdev.org/publication/guarantees-subsidies-orpaying-success-choosing-right-instrument-catalyze-private.

Basile, I., V. Bellesi and V. Singh (2020), Blended Finance Funds and Facilities - 2018 Survey, OECD Publishing, https://doi.org/10.1787/806991a2-en.

BIS (2020), Public guarantees for bank lending in response to the Covid-19 pandemic, https://www.bis.org/fsi/fsibriefs5.htm.

Boocock and Mohd Shariff (2005), "Measuring the Effectiveness of Credit Guarantee Schemes: Evidence from Malaysia", International Small Business Journal, Vol. 23/4, https://doi.org/10.1177/0266242605054054.

BSR (2017), Innovative Finance to Expand Access to Healthcare, https://www.bsr.org/en/ourinsights/report-view/innovative-finance-to-expand-access-to-healthcare.

Calice, P. (2020), Boosting credit: Public guarantees can help mitigate risk during COVID-19, World Bank, https://blogs.worldbank.org/psd/boosting-credit-public-guarantees-can-helpmitigate-risk-during-covid-19.

CDC Group (2013), CDC Standard Chartered Risk Sharing Facility, https://www.cdcgroup.com/en/our-impact/investment/standard-chartered-risk-sharing-facility/.

Convergence (2020), What role can Blended Finance play in the response to COVID-19?, https://www.convergence.finance/news-and-events/news/6lhuZ1NULofZ93jpDOIAqK/view. 
Cracan, R., A. Kresic and J. Milatovic (2020), State credit guarantee schemes: Supporting SME access to finance amid the Covid-19 crisis, EBRD, https://www.ebrd.com/what-wedo/economic-research-and-data/cse-economists/state-credit-guarantee-schemes.html.

Czech-Moravian Guarantee and Development Bank (n.d.), https://www.ecbs.org/banks/czechrepublic/czech-moravian-guarantee-and-development-bank/view-details.html, https://www.ecbs.org/banks/czech-republic/czech-moravian-guarantee-and-developmentbank/view-details.html.

Dang Le Ngoc Chuc Anh Tu, 2. (2019), Challenges in Implementing the Credit Guarantee Scheme for Small and Medium-Sized Enterprises: The Case of Viet nam, https://www.adb.org/sites/default/files/publication/496271/adbi-wp941.pdf.

EIB (2020), SME Access to Finance Initiative: European Union to boost support for small and mid- [55] sized businesses in neighbouring countries, https://www.eib.org/en/press/all/2020-015-smeaccess-to-finance-initiative-european-union-to-boost-support-for-small-and-mid-sizedbusinesses-in-neighbouring-countries.

European Commission (2020), EU and FMO scale up NASIRA guarantee in fight against the COVID-19 pandemic, https://ec.europa.eu/commission/news/eu-and-fmo-scale-nasiraguarantee-fight-against-covid-19-pandemic-2020-apr-21 en\#: :text=SearchEU\%20and\%20FMO\%20scale\%20up\%20NASIRA\%20guarantee\%20in\%20fight\%20against,b y\%20the $\% 20$ COVID\%2D19\%20pandemic.

European Commission (2020), European Health Guarantee Platform for Africa, https://ec.europa.eu/eu-external-investment-plan/content/european-health-guarantee-platformafrica en.

European Commission (2020), Global EU response to the coronavirus pandemic, https://ec.europa.eu/commission/presscorner/detail/en/QANDA 20606.

European Commission (2020), Implementation Report of the EFSD and the EFSD Guarantee, https://ec.europa.eu/commission/sites/beta-political/files/efsd-implem reportexternal support study-final.pdf.

European Commission (2019), Summaries of the EU External Investment Plan. Guarantees, https://ec.europa.eu/international-partnerships/system/files/181213-eip-28-guaranteesbrochure-final en.pdf.

European Commission (2017), Your guide to the EU External Investment Plan, https://ec.europa.eu/commission/sites/beta-political/files/external-investment-plan-guidenov17 en.pdf.

GIIN (2017), Scaling The Use of Guarantees in U.S Community Investing., https://thegiin.org/assets/GIIN Issue Brief Guarantees final\%20for\%20web.pdf.

GuarantCo (2019), Enabling long-term infrastructure finance in local currency, https://guarantco.com/gco/wp-content/uploads/2019/Documents/GuarantCo-CorporatePresentation-Q1-2019-v240419 web.pdf.

Hansen, H., J. Rand and O. Winckler Andersen (2020), Evaluation study. Guarantees and incentives in development aid., Evaluation, Learning and Quality Department, Ministry of Foreign Affairs/Danida, Denmark, http://www.netpublikationer.dk/UM/evaluation study guarantees and incentives development 
aid/Pdf/evaluation study guarantees and incentives development aid.pdf.

Huidobro and Reyes (2014), "An Evaluation of Government Loan Guarantees in Mexico", SSRN, https://papers.ssrn.com/sol3/papers.cfm?abstract id=2549399.

Humphrey, C. and A. Prizzon (2014), Guarantees for development. A review of multilateral development bank operations, ODI, https://www.odi.org/sites/odi.org.uk/files/odiassets/publications-opinion-files/9398.pdf.

IFC (2014), IFC Provides Innovative Credit Guarantee to Strengthen Indonesian Capital Markets, [40] Green Finance, https://ifcext.ifc.org/ifcext/Pressroom/IFCPressRoom.nsf/0/6E81AADC01910C1785257CAF001 FCF32.

IFC (2007), The Business of Health in Africa: Partnering with the Private Sector to Improve People's Lives, http://dx.doi.org/www.ifc.org.

InfraCo Africa (n.d.), https://infracoafrica.com/project/infracredit/, https://infracoafrica.com/project/infracredit/.

Lee, C., A. Betru and P. Horrocks (2018), , OECD and Milken Institute, https://milkeninstitute.org/sites/default/files/reports-pdf/Guaranteeing-the-Goals-FINAL-4.pdf.

Lethbridge, J. (2017), "The World Bank undermines the right to universal health coverage", Bretton Woods Project 6, https://www.brettonwoodsproject.org/2017/04/world-bank-undermines-rightuniversal-healthcare/.

Mayer, H. (2017), "Political risk insurance and its effectiveness", Commission on State Frazility, Growth and Development, https://www.theigc.org/wp-content/uploads/2018/05/Political-riskinsurance.pdf.

MIGA (2014), World Investment and Political Risk 2013, http://miga.org/documents/WIPR13.pdf.

MIGA (2011), World Investment and Political Risk Report 2010, http://www.miga.org/sites/default/files/archive/Documents/WIPR10ebook.pdf.

MIGA (2008), The online glossary of the Political Risk Insurance Centre, https://www.miga.org/report/glossary-terms-used-political-risk-insurance-industry.

Mirabile, M., J. Benn and C. Sangaré (2013), "Guarantees for Development", OECD Development Co-operation Working Papers, No. 11, OECD Publishing, Paris, https://dx.doi.org/10.1787/5k407/x5b8f8-en.

Multilateral Investment Guarantee Agency (n.d.), https://www.miga.org/.

OECD (2021), "Converged Statistical Reporting Directives for the Creditor Reporting System (CRS) and the Annual DAC Questionnaire: Reporting methods for private sector instruments (Annex 23)", Converged Statistical Reporting Directives for the Creditor Reporting System (CRS) and the Annual DAC Questionnaire: Reporting methods for private sector instruments (Annex 23), https://one.oecd.org/document/DCD/DAC/STAT(2020)44/ADD3/REV2/en/pdf.

OECD (2020), COVID-19 Government Financing Support Programmes for Businesses, http://www.oecd.org/finance/COVID-19-Government-Financing-Support-Programmes-forBusinesses.pdf. 
OECD (2020), DAC methodologies for measuring the amounts mobilised from the private sector by official development finance interventions, https://www.oecd.org/dac/financing-sustainabledevelopment/development-finance-standards/DAC-Methodologies-on-Mobilisation.pdf.

OECD (2020), OECD Policy Responses to Coronavirus (COVID-19) Strengthening health systems during a pandemic: The role of development finance, https://www.oecd.org/coronavirus/policyresponses/strengthening-health-systems-during-a-pandemic-the-role-of-development-finance$\underline{\mathrm{f} 762 \mathrm{bf} 1 \mathrm{cl}}$.

OECD (2019), Better Criteria for Better Evaluation. Revised Evaluation Criteria, Definitions and Principles for Use., http://www.oecd.org/dac/evaluation/revised-evaluation-criteria-dec2019.pdf.

OECD (2018), Making Blended Finance Work for the Sustainable Development Goals, OECD Publishing, Paris, https://dx.doi.org/10.1787/9789264288768-en.

OECD (2016), Private Sector Peer Learning. Mechanism profiles: AGF, https://www.oecd.org/dac/peer-reviews/African-Guarantee-Fund.pdf.

OECD (n.d.), Amounts mobilised from the private sector for development (webpage), http://www.oecd.org/development/stats/mobilisation.htm.

OECD/UNCDF (2020), Blended Finance in the Least Developed COuntries 2020: Supporting a Resilient COVID-19 Recovery, https://doi.org/10.1787/57620d04-en.

Pereira dos Santos, P. (2018), Introductory Guide to Infrastructure Guarantee Products from Multilateral Development Banks, IDB, https://publications.iadb.org/en/introductory-guideinfrastructure-guarantee-products-multilateral-development-banks.

Private Infrastructure Development Group (PIDG) (n.d.), guarantco.com, https://guarantco.com/

Ramanujam Bandura (2019), Innovations in Guarantees for Development, https://csis-websiteprod.s3.amazonaws.com/s3fspublic/publication/191016 BanduraRamanujam Innovations WEB.pdf.

Saadani, Arvai and Rocha (2011), "A review of credit guarantee schemes in the Middle East and North Africa Region.", World Bank Policy Research Working Paper, https://papers.ssrn.com/sol3/papers.cfm?abstract id=1794917.

Sida (2019), Sida's Guarantee Portfolio, https://www.sida.se/contentassets/983246ffbe9641ac880388cf8d6730a9/10204203 guarantee portfolio 2019 webb.pdf.

Sida (2018), Evaluation of Health Guarantee to Centenary Rural Development Bank in Uganda, https://www.sida.se/contentassets/3af55385d03c4da295bd3565fbf535c8/de2018 26 62177en. pdf.

Sida (2017), Information Brief: Guarantees. Unlocking capital for development efforts, https://publikationer.sida.se/contentassets/b5364177ab9645aa9b08b8a2cef627f2/30213947 si da infoblad guarantees webb.pdf.

Sida (2016), Evaluation of Sida's use of guarantees for market development and poverty reduction, https://publikationer.sida.se/contentassets/a99e846c5eaf48268efb1f99a0de0edf/36729336- 
4134-4ece-8f9f-afab49824678.pdf.

Sida (2015), Guarantee Example Corporate Bond, https://www.sida.se/contentassets/18561426370c4d5782dacd71e3841d41/8cf77028-4eee4158-967a-367c23a10dad.pdf.

Stallworthy et al. (2014), "Roundtable discussion: what is the future role of the private sector in health?", Global Health, https://globalizationandhealth.biomedcentral.com/articles/10.1186/1744-8603-10-55.

USAID (2014), "Supported by USAID guarantee, city of dakar announces first west african municipal bond at usaid frontiers in development", https://2012-2017.usaid.gov/newsinformation/press-releases/sep-18-2014-supported-usaid-guarantee-city-dakar-announces-firstwest-african.

WEF (2016), Risk Mitigation Instruments in Infrastructure. Gaps assessment., http://www3.weforum.org/docs/WEF Risk Mitigation Instruments in Infrastructure.pdf.

Winckler Andersen, O. et al. (2019), "Blended Finance Evaluation: Governance and Methodological Challenges", OECD Development Co-operation Working Papers, No. 51, OECD Publishing, Paris, https://dx.doi.org/10.1787/4c1fc76e-en.

Wolf, A. and B. Toebes (2016), "Assessing Private Sector Involvement in Health Care and Universal Health Coverage in Light of the Right to Health", Health and Human Rights, https://www.ncbi.nlm.nih.gov/pmc/articles/PMC5394993/.

World Bank (2020), Covid-19 Approach Paper, http://documents1.worldbank.org/curated/en/136631594937150795/pdf/World-Bank-GroupCOVID-19-Crisis-Response-Approach-Paper-Saving-Lives-Scaling-up-Impact-and-GettingBack-on-Track.pdf.

World Bank (2009), The World Bank Group Guarantee Instruments, 1990-2007, https://ieg.worldbankgroup.org/evaluations/world-bank-group-guarantee-instruments-1990$\underline{2007}$.

World Bank Group (2016), Guarantee Products Guidance Note, https://ppp.worldbank.org/publicprivate-partnership/library/world-bank-group-guarantee-products-guidance-note.

www.cdcgroup.com (n.d.), , http://www.cdcgroup.com. 
Notes

1 The AFD is a key actor among the DAC's bilateral financial institutions using development guarantees with USD 270 million private finance mobilised by guarantees in 2018. Its flagship guarantee scheme, ARIZ, is a final loss guarantee offered to financial institutions to cover 50 to $75 \%$ of an individual loan or a loan portfolio for SMEs and microfinance institutions. It has been operating for more than 10 years; https://www.afd.fr/en/ressources/brochure-ariz

2 Prior to the EFSD, the EU had already made use of guarantees to promote development in partner countries under its External Lending Mandate (ELM) guarantees to the European Investment Bank (EIB).

3 The first EFSD guarantee programmes accepted by the EFSD Operational Board in 2018 included submissions by 11 partner financial institutions (AECID, AFD, AfDB, CDP, COFIDES, EBRD, EIB, EDFI, FMO, IFC, KfW).

${ }^{4}$ The term "vehicle" covers DFIs, investment funds and other special-purpose programmes that members have established to extend financing to private sector entities in developing countries.

${ }^{5}$ There are examples of a higher leverage factor of guarantees used by MDBs, for instance the African Development Fund (ADF) which is the AfDB's concessional financing window for LICs and fragile/transition economies. ADF guarantees only consume $25 \%$ of the guarantee amount which is equivalent to a $4 \mathrm{x}$ leverage factor.

${ }^{6}$ The Milken Institute-OECD report recommends that donors seek a policy exception that would allow certain SDG-exposures to qualify as HQLA.

7 This requirement of a counter-guarantee is argued by (Mirabile, Benn and Sangaré, $2013_{[1]}$ ) to create a disincentive for country level usage of guarantees since the exposure is recorded dollar for dollar against the beneficiary country's borrowing headroom.

${ }^{8} \mathrm{~A}$ more thorough discussion of the debt sustainability issue may be found in the following OECD publication, noting that loan guarantees need to be used in conjunction with other policies, and that governments need to consider the impact that guarantees will have on leverage/indebtedness in already highly-leveraged/indebted systems: OECD (2020), "COVID-19 Government Financing Support Programmes for Businesses", OECD Paris, www.oecd.org/finance/COVID-19-Government-FinancingSupport-Programmes-for-Businesses.pdf.

${ }^{9}$ Interviews with European Commission and the African Guarantee Fund.

10 Only five countries - Angola, Bangladesh, Myanmar, Senegal and Zambia - received more than half of all private finance mobilised through guarantees in LDCs.

${ }^{11}$ See also: Open letter to the EU on the use of ODA to support private investments in developing countries, https://www.eurodad.org/open letter eu oda

${ }^{12}$ This is also the case of investments in the water and sanitation sectors, which contribute to reducing the transmission of infectious diseases. Examples of the use of guarantees in the water and sanitation sectors can be found in OECD (2019), Making Blended Finance Work for Water and Sanitation: Unlocking 
Commercial Finance for SDG 6, OECD Studies on Water, OECD Publishing, Paris, https://doi.org/10.1787/5efc8950-en

13 There seems to be an increasing reliance on private actors to provide, finance, and supply health care goods and services in developing countries. In Africa, for example, the IFC has found that "the private sector already delivers about half of Africa's health products and services" (IFC, 2007[65]).

${ }^{14}$ https://www.gavi.org/sites/default/files/covid/covax/COVAX-AMC-Donors-Table-08.10.2020.pdf 


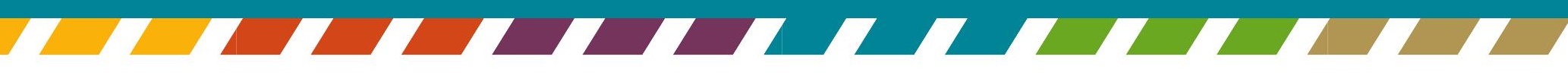

